\title{
A Review on Nanocomposite Materials for Rechargeable Li-ion Batteries
}

\author{
Dervis Emre Demirocak $^{1, *}$ (D), Sesha S. Srinivasan ${ }^{2}$ (D) and Elias K. Stefanakos ${ }^{3}$ \\ 1 Department of Mechanical and Industrial Engineering, Texas A\&M University-Kingsville, \\ Kingsville, TX 78363, USA \\ 2 Department of Physics, Florida Polytechnic University, 4700 Research Way, Lakeland, FL 33805, USA; \\ ssrinivasan@flpoly.org \\ 3 Clean Energy Research Center, College of Engineering, University of South Florida, Tampa, FL 33620, USA; \\ estefana@usf.edu \\ * Correspondence: Dervis.Demirocak@tamuk.edu; Tel.: +1-361-5932-029
}

Academic Editor: Carlo Casari

Received: 15 June 2017; Accepted: 12 July 2017; Published: 17 July 2017

\begin{abstract}
Li-ion batteries are the key enabling technology in portable electronics applications, and such batteries are also getting a foothold in mobile platforms and stationary energy storage technologies recently. To accelerate the penetration of Li-ion batteries in these markets, safety, cost, cycle life, energy density and rate capability of the Li-ion batteries should be improved. The Li-ion batteries in use today take advantage of the composite materials already. For instance, cathode, anode and separator are all composite materials. However, there is still plenty of room for advancing the Li-ion batteries by utilizing nanocomposite materials. By manipulating the Li-ion battery materials at the nanoscale, it is possible to achieve unprecedented improvement in the material properties. After presenting the current status and the operating principles of the Li-ion batteries briefly, this review discusses the recent developments in nanocomposite materials for cathode, anode, binder and separator components of the Li-ion batteries.
\end{abstract}

Keywords: Li-ion batteries; nanocomposite materials; cathode; anode; binder; separator

\section{Introduction}

Rechargeable (rechargeable battery and secondary battery terms are used interchangeably throughout this article) batteries are one of the key technologies in today's information-rich and mobile society. For a long time, the most important application for rechargeable batteries has been the starter-ignition-lighting (SLI) batteries in motor vehicles. With the rapid market penetration of the portable electronics such as laptops, smartphones and tablets since 2000s, the rechargeable battery market significantly expanded. More recently, interest in plug-in hybrid electric vehicles (PHEV) and electric vehicles (EV) has been driving the further expansion of the rechargeable battery market, specifically Li-ion batteries. Additionally, large-scale utilization of rechargeable batteries for peak shaving and load leveling applications in the power grid has been envisioned by many, but is still in very early phases [1]. Apart from the aforementioned applications, rechargeable batteries are also critical for e-bikes and power tools [2]. Considering the importance of the rechargeable batteries in a variety of applications, the future of these batteries looks brighter than ever.

Rechargeable batteries comprise three quarters of the global battery market, and the most important rechargeable battery chemistries are lithium-ion (Li-ion), lead acid, nickel-metal-hydride $(\mathrm{NiMH})$ and nickel-cadmium (Ni-Cd) as shown in Figure 1 [3]. 


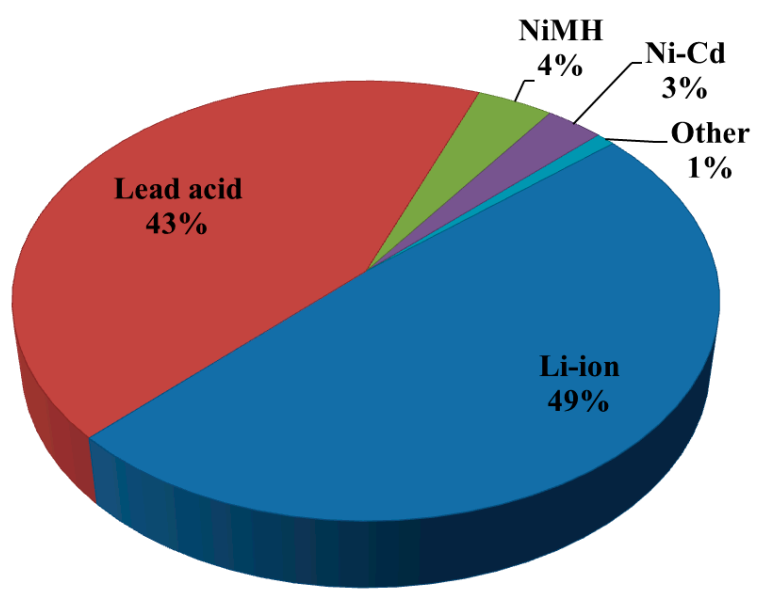

Figure 1. Market share of rechargeable battery chemistries in 2009 [3].

Li-ion and lead acid batteries dominate the market, and Li-ion is the fastest-growing market. The lead acid batteries are mostly utilized in the SLI, stationary (i.e., back-up power) and deep cycle applications, whereas Li-ion batteries are preferred in portable electronics. In recent years, Li-ion chemistry is making inroads to the lead acid market (i.e., SLI batteries), but the lead acid battery market still continues to grow due to its low cost and maturity [4]. The NiMH and Ni-Cd batteries have much smaller market share compared to lead acid and Li-ion batteries, and their share continues to shrink because Li-ion batteries are rapidly replacing these types of batteries. The NiMH batteries are still utilized in some hybrid electric vehicles (HEV) such as the Toyota Prius, while Ni-Cd batteries are employed in power tools due to their high rate capability. The introduction of the Li-ion chemistries with high rate capability such as $\mathrm{LiFePO}_{4}$ significantly dropped the market share of the Ni-Cd batteries. The popularity of Li-ion chemistry is associated with its high gravimetric and volumetric energy density as well as the significant cost reduction during the last decade. The main characteristics of the most common battery chemistries are summarized in Table $1[5,6]$.

Table 1. Comparison of different battery chemistries [5,6].

\begin{tabular}{ccccc}
\hline \multirow{2}{*}{ Properties } & \multicolumn{3}{c}{ Rechargeable Battery Chemistry } \\
\cline { 2 - 5 } & Li-ion & Lead Acid & NiMH & Ni-Cd \\
\hline Specific energy density $(\mathrm{Wh} / \mathrm{kg})$ & $90-190$ & $30-55$ & $60-120$ & $45-80$ \\
Cycle life $(80 \%$ of initial capacity) & $500-2000$ & $200-300$ & $300-500$ & 1000 \\
Cell voltage $(\mathrm{V})$ & $3.3-3.8$ & 2.0 & 1.2 & 1.2 \\
Self-discharge $/$ month at $25^{\circ} \mathrm{C}$ & $<5 \%$ & $5-15 \%$ & $30 \%$ & $20 \%$ \\
Safety & Protection circuit is mandatory & 1881 & Thermally stable & 1950 \\
Commercialized in & 1991 & High & Low & High \\
Toxicity & Low &
\end{tabular}

Despite the significant growth of the rechargeable battery market since 2000s, further improvements in energy density and cost reduction are required for EV and grid level energy storage applications. The progress in rechargeable battery technologies is rather slow, the energy density of the rechargeable batteries has only increased $3 \%$ per year on average during the last 60 years, and the rate of energy density increase has been slightly higher since the introduction of Li-ion batteries in 1991 as seen in Figure 2 [7]. However, the current rate of increase (i.e., 5-8\%) in the energy density of secondary batteries is not sufficient to meet the targets set by the United States (U.S.) Department of Energy (DOE) [8]. 


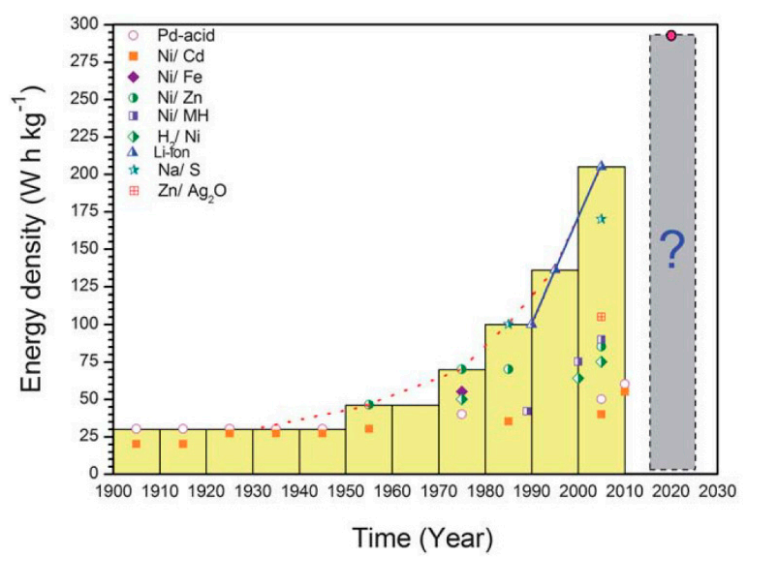

Figure 2. Increase in the energy density of the secondary batteries since 1900s. Adapted with permission from [7], (C) Royal Society of Chemistry, 2011.

There are two ways to improve the energy density of the secondary batteries: (i) by introducing new battery chemistries; and (ii) by employing enhanced battery designs and manufacturing processes (i.e., engineering improvements) to reduce the weight and volume of the inactive components in the existing battery chemistries. A closer look at Figure 2 shows that a quantum leap in energy density of secondary batteries was usually achieved when new battery chemistries were introduced. Therefore, it is critical to develop advanced chemistries and materials to facilitate the higher market penetration of secondary batteries.

The U.S. DOE "EV Everywhere" initiative was launched in 2012, and the energy storage targets for battery systems identified by this initiative are given in Table 2 [8]. Although significant progress has been made in improving the cost and energy density of batteries, it is estimated the targets can only be achieved by utilizing advanced Li-ion chemistries and materials.

Among the targets listed in Table 2, the cost target for the Li-ion batteries is critical to make PHEV and EV cost competitive with the gasoline powered cars. As shown in Figure 3, cost of Li-ion battery packs has significantly dropped during the last 10 years, mostly due to efforts by the EV market leaders such as Tesla (i.e., Model S) and Nissan (i.e., Leaf). The most recent cost estimate in 2016 for Li-ion battery packs is $\sim \$ 190 / \mathrm{kWh}$ indicating that the U.S. DOE cost target for battery energy systems for 2022 is well within reach [9].

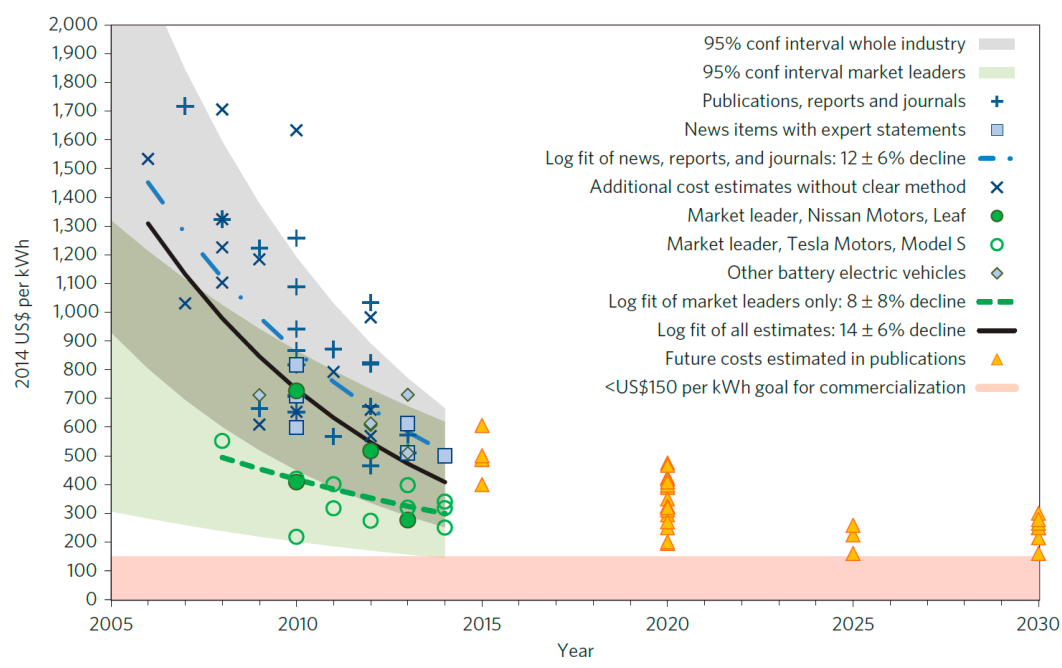

Figure 3. Cost of Li-ion battery packs in EV. Adapted with permission from [10], (c) Nature Publishing Group, 2015. 
Table 2. The U.S. DOE “EV Everywhere” energy storage targets for battery systems [8].

\begin{tabular}{ccc}
\hline Metrics & Status in 2012 & Target for 2022 \\
\hline Battery cost $(\$ / \mathrm{kWh})$ & 500 & 125 \\
Pack specific energy $(\mathrm{Wh} / \mathrm{kg})$ & $80-100$ & 250 \\
Pack energy density $(\mathrm{Wh} / \mathrm{L})$ & 200 & 400 \\
Pack specific power $(\mathrm{W} / \mathrm{kg})$ & 500 & 2000 \\
\hline
\end{tabular}

The operation of a secondary battery relies on various interfacial processes at the nanoscale; therefore, manipulating the material properties at the nanoscale is essential for developing advanced materials. The most common strategies to improve the battery materials are particle size reduction, morphology control, composite formation, doping, functionalization, coating, encapsulation and electrolyte modification [11]. The battery electrodes (i.e., anode and cathode) that determine the overall performance of a battery are composite materials. A typical composite battery electrode includes active material, conductive carbon additive and a binder. Each of these components is vital to the operation of a rechargeable battery, and their performances can be improved by utilizing nanocomposites.

In this review article, the basics of rechargeable batteries and the key developments in nanocomposite materials are discussed with a focus on Li-ion batteries due to their technological significance. Specifically, the nanocomposite-based developments in cathode, anode, binder and separator materials for Li-ion batteries are discussed in detail. Readers can also benefit from the following review articles based exclusively on cathodes [12,13], anodes [14,15], binders [16,17] and separators [18].

\section{Basics of Rechargeable Batteries}

A rechargeable battery or a secondary battery is a type of battery that can be discharged and charged (i.e., cycled) multiple times over its lifetime as opposed to a primary battery, which can only be discharged one time only before being discarded. The smallest packaged unit of a battery is the cell. Most applications require higher voltages (i.e., PHEV/EV battery packs are in the range of 100-400 V, SLI batteries are $\sim 12 \mathrm{~V}$ ) than a single cell (i.e., $\sim 3-4 \mathrm{~V}$ for Li-ion) can provide; therefore, multiple cells are assembled into modules (i.e., in a typical EV battery module there are 4 cells in a 2 series and 2 parallel formation) in parallel or in series configuration depending on the application. Battery pack is the final product formed by connecting multiple modules together. A battery pack is custom designed for a specific application and includes battery management system, sensors for voltage, current, and temperature measurements, cooling system in addition to battery modules.

A typical Li-ion rechargeable battery cell is composed of a cathode (positive electrode), an anode (negative electrode), a separator filled with an electrolyte and the current collectors for both anode and cathode. The electrodes (i.e., cathode and anode) in Li-ion batteries are composite materials, which include active materials (i.e., typically, metal oxides for cathode and graphite for anode) for storing $\mathrm{Li}$ ions, conductive carbon additive to improve the electronic conductivity and a binder to keep the active materials together and attached to the current collector. The cell components that are not involved in Li storage are called the inactive materials (i.e., current collector, separator, electrolyte, binder and carbon additive). The inactive components do not directly contribute to the cell capacity so it is critical to minimize their content; however, the inactive components play a remarkable role in the operation and safety of a battery. The cross-sectional view of a cylindrical Li-ion battery is given in Figure 4. 


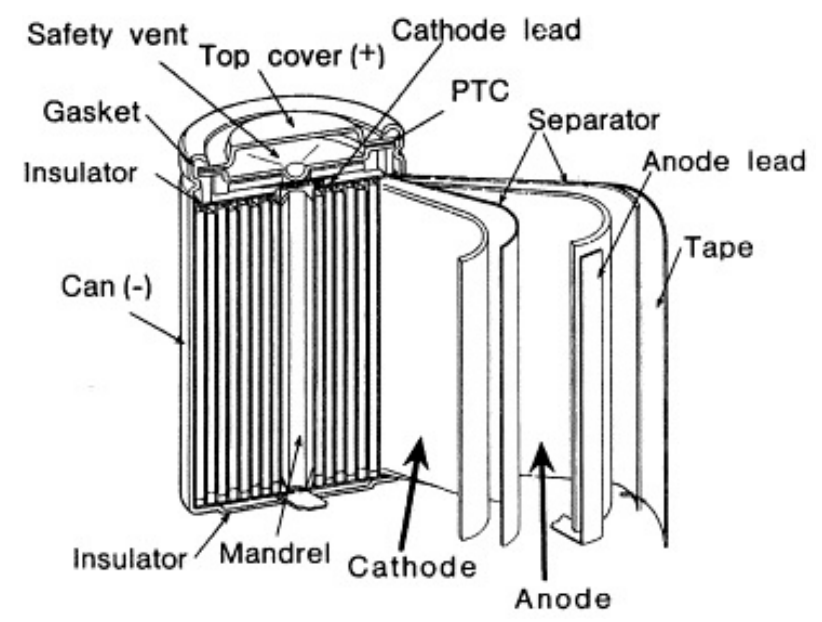

Figure 4. Schematic of a cylindrical Li-ion battery. Adapted with permission from [19], @ Elsevier, 2001.

The energy and power characteristics of an electrochemical cell can be determined by utilizing thermodynamic and kinetics relations. The net useful energy of an electrochemical cell can be calculated by the following thermodynamic equation [20]:

$$
\Delta G=-n F E
$$

where $\Delta G$ is the Gibbs free energy, $n$ is the number of electrons transferred per mole of reactants, $F$ is the Faraday constant, and $E$ is the cell potential. The Equation (1) implies that, the higher the cell potential (i.e., E) the higher the capacity of an electrochemical cell assuming number of electrons transferred per mole of reactants are the same (i.e., this is the case for different $\mathrm{Li}$-ion chemistries such as $\mathrm{LiCoO}_{2}$ and $\mathrm{LiFePO}_{4}$ ). To maximize the useful energy of an electrochemical cell, the difference between the cathode and anode potentials (i.e., open circuit voltage, $E_{\mathrm{OCV}}$ ) should be as large as possible, and this is the main reason behind the research efforts on developing high voltage batteries [21].

Although the thermodynamic relations are useful in understanding the limits of an electrochemical cell, the practical batteries do not operate under equilibrium conditions hence deviate from thermodynamic equilibrium condition when current is withdrawn due to kinetic limitations (i.e., polarization effects, $\eta)$. The terminal cell potential $\left(E_{\mathrm{T}}\right)$ of an electrochemical cell is dependent on three different types of polarization effects: (a) activation polarization which is related to charge transfer reactions occurring at the electrode-electrolyte interface, (b) ohmic polarization which is the overall internal resistance of the cell components, and (c) concentration polarization which is related to mass transfer limitations during cell operation. The terminal cell potential is given by Equation (2) [20] as follows:

$$
E_{\mathrm{T}}=E_{\mathrm{OCV}}-\eta
$$

The polarization effects can be observed on a discharge curve of a battery as shown in Figure 5 . The discharge curve can be utilized to calculate the capacity of the cell, and to understand the effects of the C-rate and temperature on the cell capacity. A C-rate is a measure of the rate at which a battery is charged or discharged relative to its maximum capacity. Charging a battery at $1 \mathrm{C}$ rate would take $1 \mathrm{~h}$ to completely charge the battery [22]. 


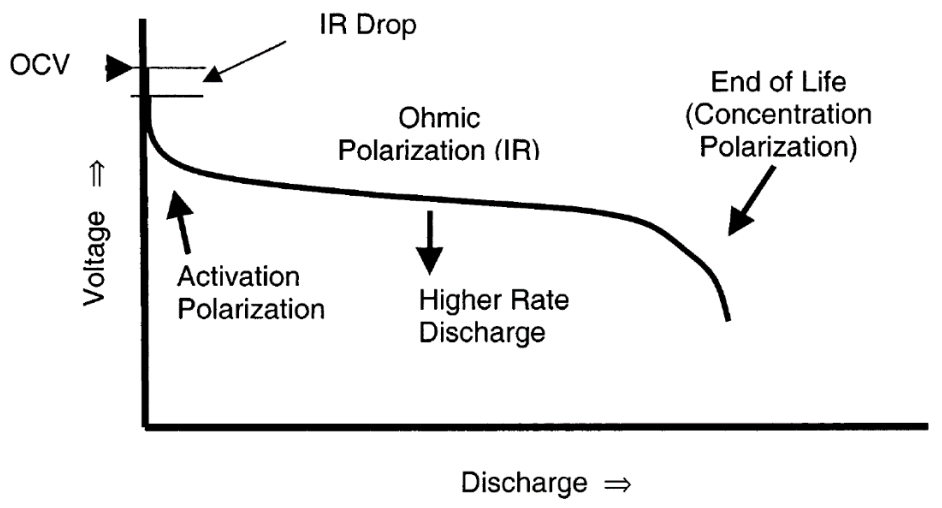

Figure 5. The discharge curve of a battery and the effects of different types of polarization. Adapted with permission from [20], (C) American Chemical Society, 2004.

Additional information regarding electrode kinetics can be obtained by electrochemical impedance spectroscopy (EIS) [23-25]. EIS is a non-destructive technique, and can reveal various reaction steps during Li-ion intercalation/deintercalation. Each electrode reaction has a distinctive impedance pattern, which can be modeled by an equivalent-circuit model. The depressed semicircle, as seen in Figure $6 \mathrm{~b}$, in an EIS curve indicates an inhomogeneous electrode surface. Therefore, constant phase element $(\mathrm{CPE})$ is used in the equivalent circuit model rather than pure capacitance as in Figure 6c. The EIS of $\mathrm{InVO}_{4}$ (indium vanadium oxide) anode is shown in Figure 6 where Re is the combined resistance (R) of electrolyte and cell components, Rsf $+\mathrm{ct}$ is resistance due to surface film (sf) and charge transfer (ct), CPEsf $+\mathrm{dl}$ is the capacitance due to surface film and double layer (dl), CPEb is the bulk (b) capacitance, $\mathrm{Rb}$ is the bulk resistance, Ws is the Warburg impedance that represents the solid state diffusion of Li-ions through the electrode lattice, and Cint is the intercalation (int) capacitance (C) [23]. Impedance values are highly dependent on voltage values during discharge/charge as shown in Figure 6a.

(a)

(b)
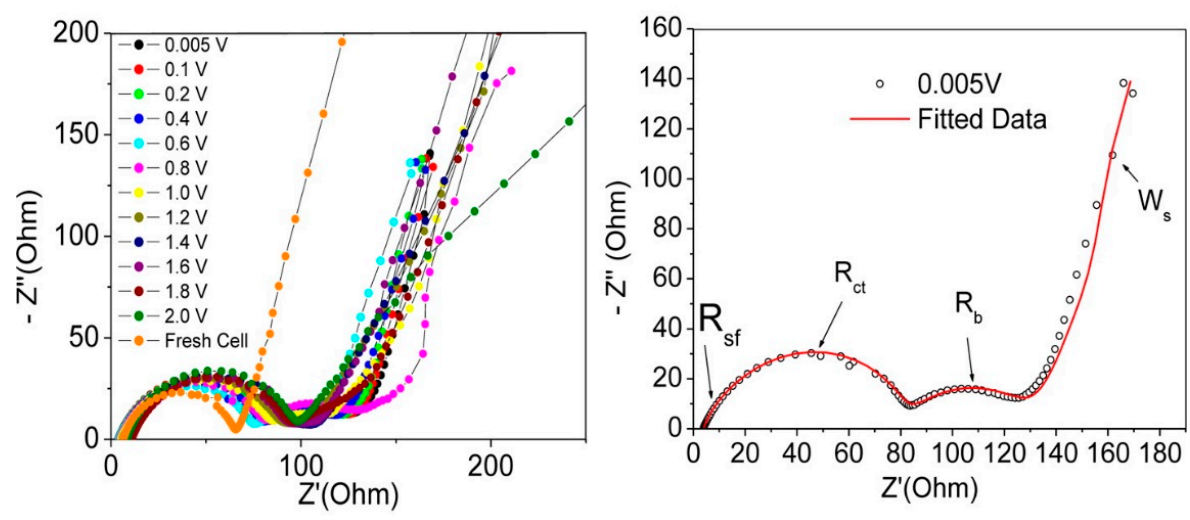

(c)

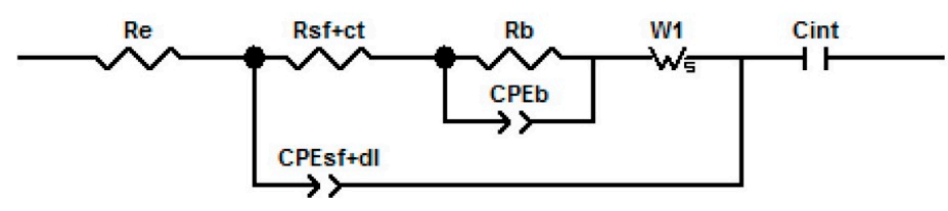

Figure 6. (a) EIS of InVO4 anode at different voltages; (b) EIS of InVO4 at $0.005 \mathrm{~V}$ and (c) the corresponding equivalent-circuit model. Adapted with permission from [23], ( ) American Chemical Society, 2013. 


\section{Li-ion Batteries}

Li-ion batteries are the most popular battery chemistry as of today due to their high gravimetric and volumetric energy density as compared to the other rechargeable battery chemistries. The main components of a Li-ion battery are the cathode, anode, electrolyte, separator and current collector. The schematic of a Li-ion battery is shown in Figure 7.

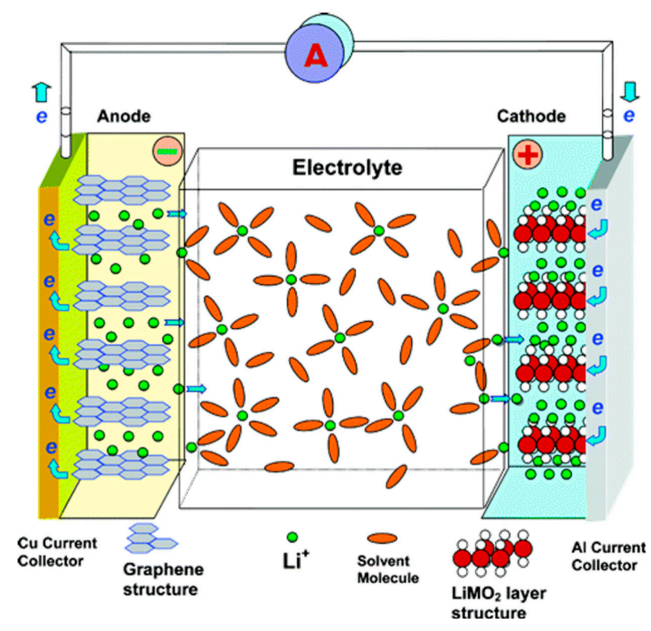

Figure 7. Schematic of a Li-ion battery. Adapted with permission from [26], (c) American Chemical Society, 2004.

During the operation of a Li-ion battery, Li ions shuttle back and forth in between cathode and anode through the electrolyte absorbed in the separator. Both cathode (i.e., transition metal oxides) and anode (i.e., graphite) are intercalation compounds with layered structures where Li ions can be reversibly inserted and removed. The primary reason behind using intercalation compounds instead of pure metallic $\mathrm{Li}$ as an anode is the poor safety and cycle life of the $\mathrm{Li}$-ion batteries with metallic $\mathrm{Li}$ anode due to dendrite formation [27]. The cathode, anode, binder and separator are discussed in more detail in the following sections.

\section{Cathode}

Mostly, intercalation-type cathode materials based on transition metal oxides are utilized in the commercial Li-ion batteries. Basically, there are three types of cathodes: (i) Layered oxides such as $\mathrm{LiCoO}_{2}$ which is the first Li-ion chemistry that was discovered in 1980, and commercialized by SONY in 1991 [27-29]. The $\mathrm{LiCoO}_{2}$ chemistry still dominates the Li-ion battery market (i.e., 37\%) [30]. The layered oxides have two dimensional $\mathrm{Li}$ ion diffusion channels; (ii) Spinels such as $\mathrm{LiMn}_{2} \mathrm{O}_{4}$ has three dimensional $\mathrm{Li}$ ion diffusion channels, and was discovered in 1983 [31]; and (iii) Olivines such as $\mathrm{LiFePO}_{4}$ has one dimensional $\mathrm{Li}$ ion diffusion channels, and was discovered in 1997 [32]. The crystal structures of these three main types of intercalation cathodes are shown in Figure 8.
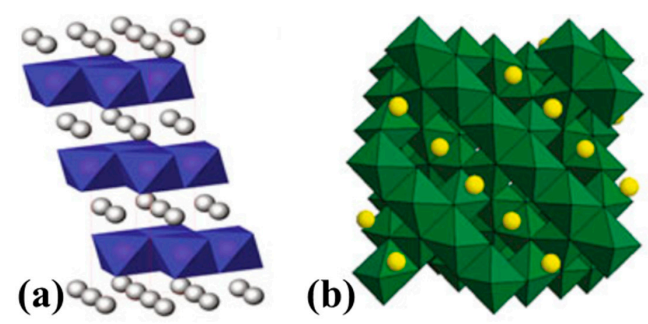

(c)

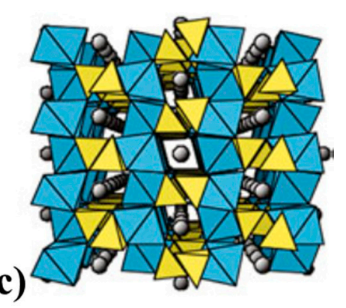

Figure 8. The structure of the (a) layered oxide $\mathrm{LiCoO}_{2} ;(\mathbf{b})$ spinel $\mathrm{LiMn}_{2} \mathrm{O}_{4}$; and (c) olivine $\mathrm{LiFePO}_{4}$. Adapted with permission from [33], @) Springer, 2013. 


\subsection{Layered Oxides, $\mathrm{LiMO}_{2}(\mathrm{M}=\mathrm{Co}, \mathrm{Mn}$, Ni and Their Mixtures)}

$\mathrm{LiCoO}_{2}$ is the first layered oxide type cathode material with a practical capacity of $140 \mathrm{mAh} / \mathrm{g}$ and average voltage of $3.9 \mathrm{~V}$ vs. $\mathrm{Li} / \mathrm{Li}^{+}$. In practice, only half of the lithium (i.e., $1>x>0.5$ ) stored in $\mathrm{Li}_{\mathrm{x}} \mathrm{CoO}_{2}$ is extracted because further $\mathrm{Li}$ extraction (i.e., $\mathrm{x}<0.5$ which corresponds to upper cut-off voltage of $4.2 \mathrm{~V}$ ) triggers structural transition from a hexagonal to monoclinic phase as well as amplifies the side reactions, and results in quick degradation of the cycle life. Significant number of studies was conducted to understand the capacity fading mechanism over $4.2 \mathrm{~V}$ as well as to improve the capacity of $\mathrm{LiCoO}_{2}$ by pushing the upper cut-off voltage above $4.2 \mathrm{~V}$ while keeping the cycle life at a reasonable level (i.e., $~ 500$ cycles) [34-37]. It was shown by many that the cycle life of $\mathrm{LiCoO}_{2}$ at higher voltages (i.e., $>4.2 \mathrm{~V}$ ) can be improved by metal oxide coatings such as $\mathrm{Al}_{2} \mathrm{O}_{3}, \mathrm{SnO}_{2}, \mathrm{ZrO}_{2}, \mathrm{TiO}_{2}$, $\mathrm{MgO}$, [34,38-42], metal phosphate coatings such as $\mathrm{AlPO}_{4}$ [43-46], metal fluoride coatings such as $\mathrm{AlF}_{3}$ and $\mathrm{LaF}_{3}[47,48]$ and multicomponent metal fluoride coatings such as aluminum-tungsten-fluoride $\left(\mathrm{AlW}_{\mathrm{x}} \mathrm{F}_{\mathrm{y}}\right)$ [49]. Although the underlying reasons for such an improvement in cycle life of $\mathrm{LiCoO}_{2}$ at higher cut-off voltages due to coatings are still debatable [35,50,51], following mechanisms have been suggested: coating (i) inhibits the structural transformation [34,52], (ii) acts as a physical barrier, Figure 9, between the electrolyte and the active material, and prevents the trace amounts of hydrogen fluoride (HF) and water present in the electrolyte from reaching the active material thus effectively suppresses cobalt dissolution and the associated oxygen evolution [53,54], (iii) converts Lewis acids which in return corrode the insulating surface species and improves the electronic conductivity of the solid electrolyte interface (SEI) layer on $\mathrm{LiCoO}_{2}$ [50].

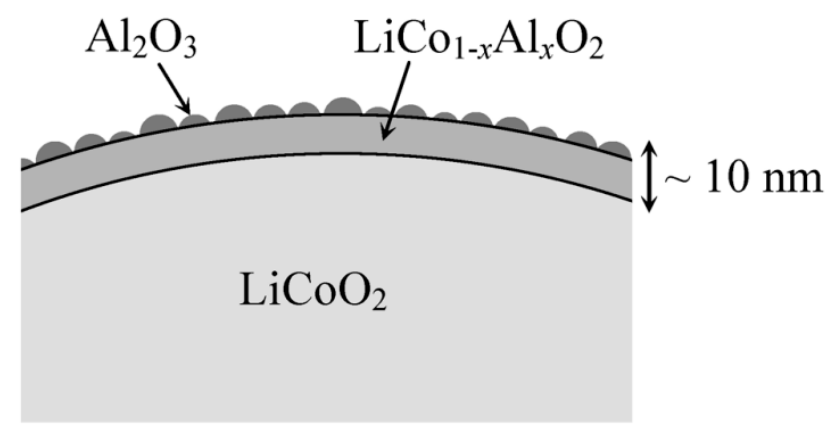

Figure 9. Schematic view of the formation of the solid solution at the coating/active material interface. Adapted with permission from [54], (C) American Chemical Society, 2009.

In addition to the cycle life, rate capability (i.e., electronic conductivity) can also be improved by metal oxide coatings [55]. Additionally, thermal stability of the $\mathrm{LiCoO}_{2}$ can be improved by a metal oxide coating, which is desirable for safety purposes $[37,43,55]$. The sample preparation technique can also affect the cycle life of $\mathrm{LiCoO}_{2}$. Tan et al. showed that $\mathrm{LiCoO}_{2}$ prepared by the eutectic $\mathrm{LiNO}_{3}-\mathrm{LiCl}$ molten salt can attain 80 charge-discharge cycles in the 2.5-4.4 V range without any capacity loss which was associated with the inhibited structural transitions (i.e., hexagonal $\leftrightarrow$ monoclinic $\leftrightarrow$ hexagonal) of $\mathrm{LiCoO}_{2}[56]$.

One of the problems of the $\mathrm{LiCoO}_{2}$ chemistry for large scale applications is its high cost due to limited Co sources; additionally, $\mathrm{Co}$ is a toxic substance, and environmentally friendly commercial scale recycling technologies are yet to be developed [57,58]. $\mathrm{LiNiO}_{2}$ is a lower cost cathode compared to $\mathrm{LiCoO}_{2}$, and has a similar structure to $\mathrm{LiCoO}_{2}$; however, it is difficult to obtain stoichiometric $\mathrm{LiNiO}_{2}$, and synthesis conditions significantly affect its compositional and structural properties which impede the widespread utilization of $\mathrm{LiNiO}_{2}$ cathode [59]. $\mathrm{LiNiO}_{2}$ exhibits similar structural transformations as in $\mathrm{LiCoO}_{2}$; thus, the upper cut-off voltage is $4.2 \mathrm{~V}$ (i.e., $\mathrm{x} \sim 0.5$ ), and beyond $4.2 \mathrm{~V}$ cycle-life quickly degrades. Several metal oxide coatings such as $\mathrm{ZrO}_{2}$ have shown to improve the cycling stability of $\mathrm{LiNiO}_{2}$ by inhibiting the structural transformation as shown by ex-situ X-ray 
diffraction (XRD) and cyclic voltammetry (CV) experiments [60]. The thermal stability of $\mathrm{Li}_{\mathrm{x}} \mathrm{Ni}_{1-\mathrm{x}} \mathrm{O}_{2}$ is also of great concern and it is function of $\mathrm{Li}$ content (i.e., $\mathrm{x}$ ), the smaller the Li content (i.e., $\mathrm{x}<0.5$ ) the less thermally stable the $\mathrm{LiNiO}_{2}$. In addition to the problems associated with the capacity fading, overcharging the $\mathrm{LiNiO}_{2}$ also poses a safety risk; however, thermal stability of $\mathrm{LiNiO}_{2}$ can be improved by $\mathrm{Mg}$ doping and coating [33,61]. $\mathrm{LiNiO}_{2}$ can also be prepared using a single source precursor (i.e., $\left.\left.\mathrm{Li}\left(\mathrm{H}_{2} \mathrm{O}\right) \mathrm{Ni}\left(\mathrm{N}_{2} \mathrm{H}_{3} \mathrm{CO}_{2}\right)_{3}\right] \cdot 0.5 \mathrm{H}_{2} \mathrm{O}\right)$ which is a desired synthetic route to prepare this cathode material in large scale [62].

$\mathrm{LiMnO}_{2}$ is another layered metal oxide which is isostructural to $\mathrm{LiCoO}_{2}$; similar to $\mathrm{LiNiO}_{2}$, $\mathrm{LiMnO}_{2}$ is a low cost (i.e., Co is $\$ 23.99 / \mathrm{kg}$, Ni is $\$ 8.94 / \mathrm{kg}$ and $\mathrm{Mn}$ is $\$ 2.01 / \mathrm{kg}$ as of 9 May 2016 [63]) and environmentally friendly cathode material compared to $\mathrm{LiCoO}_{2}$. $\mathrm{LiMnO}_{2}$ irreversibly transforms from layered structure into spinel structure upon cycling and its capacity fades quickly [64,65]. The $\mathrm{Al}_{2} \mathrm{O}_{3}$ and $\mathrm{CoO}$ coatings improve the cycle life of $\mathrm{LiMnO}_{2}$ by impeding $\mathrm{Mn}$ dissolution and lattice instability due to Jahn-Teller distortion [66,67].

Another strategy to lower the cost of $\mathrm{LiCoO}_{2}$ is to partially or fully substitute $\mathrm{Co}$ with $\mathrm{Ni}, \mathrm{Mn}$ and $\mathrm{Al}$ such as $\mathrm{LiNi}_{1 / 3} \mathrm{Mn}_{1 / 3} \mathrm{Co}_{1 / 3} \mathrm{O}_{2}(\mathrm{NMC}), \mathrm{LiNi}_{0.8} \mathrm{Co}_{0.15} \mathrm{Al}_{0.05} \mathrm{O}_{2}(\mathrm{NCA}), \mathrm{LiNi}_{x} \mathrm{Co}_{1-\mathrm{x}}(0<\mathrm{x}<1)$ and $\mathrm{Li}\left(\mathrm{Ni}_{\mathrm{x}} \mathrm{Mn}_{1-\mathrm{x}}\right) \mathrm{O}_{2}(0<\mathrm{x}<1)[24,46,68-73]$. These composite cathodes derived from $\mathrm{LiCoO}_{2}$ have also higher specific capacity than the $\mathrm{LiCoO}_{2}$, and are extensively used in portable electronics.

\subsection{Spinel, $\mathrm{LiM}_{2} \mathrm{O}_{4}(\mathrm{M}=\mathrm{Mn}$, and Mixtures of $\mathrm{Co}$ and $\mathrm{Ni})$}

Spinel $\mathrm{LiMn}_{2} \mathrm{O}_{4}$ has three-dimensional $\mathrm{Li}$ ion conduction channels which translate to excellent rate capability; additionally, it is easy to synthesize $\mathrm{LiMn}_{2} \mathrm{O}_{4}$ from various precursors. $\mathrm{Mn}$ is a low cost and an earth abundant material. Spinel $\mathrm{LiMn}_{2} \mathrm{O}_{4}$ is also inherently safe due to its thermal stability [74]. On the other hand, the major problems associated with $\mathrm{LiMn}_{2} \mathrm{O}_{4}$ are $\mathrm{Mn}$ dissolution especially at high operating and storage temperatures (i.e., $55^{\circ} \mathrm{C}$ ) and the phase transition (i.e., Jahn-Teller distortion) that occurs if $\mathrm{LiMn}_{2} \mathrm{O}_{4}$ is over discharged. $\mathrm{Li}_{\mathrm{x}} \mathrm{Mn}_{2} \mathrm{O}_{4}$ has two voltage plateaus at $\sim 4 \mathrm{~V}(\mathrm{x}=0$ to 1.0$)$ and $\sim 3 \mathrm{~V}$ $(\mathrm{x}=1.0$ to 2.0$)$, and phase transition from cubic to tetragonal structure can be prevented if $\mathrm{LiMn}_{2} \mathrm{O}_{4}$ is not discharged below 3.5 V [75]. The over discharge of $\mathrm{LiMn}_{2} \mathrm{O}_{4}$ results in significant capacity fade and poor cycling hence should be avoided. The Mn dissolution is more problematic and occurs at both $3 \mathrm{~V}$ and $4 \mathrm{~V}$ voltage plateaus. It was shown by Tarascon et al. that $\mathrm{Mn}$ dissolution is a function of surface area of $\mathrm{LiMn}_{2} \mathrm{O}_{4}$ particles indicating Mn dissolution is originated at the active material-electrolyte interface [76]. The $\mathrm{LiMn}_{2} \mathrm{O}_{4}$ surface acts as a catalyst at high open circuit voltages and oxidizes the non-aqueous electrolyte producing harmful by-products, and higher temperatures accelerates these side reactions further. The dissolved $\mathrm{Mn}$ ions can also migrate to the anode side and get reduced and precipitate as $\mathrm{Mn}$ metal at the anode surface which can damage the structure of the solid electrolyte interface and increase the charge transfer resistance [77]. To circumvent the Mn dissolution problem, passivation layer needs to be formed between the active material and the electrolyte.

Various coatings and dopants such as lithium boron oxide (LBO) glass [76], $\mathrm{SiO}_{2}$ [78], $\mathrm{SnO}_{2}$ [79], $\mathrm{MgO}$ [80], $\mathrm{Ag}$ [81,82], $\mathrm{Al}$ [83], carbon nanotube (CNT) [84], $\mathrm{LiCoO}_{2}$ [85] as well as mixing with other cathode materials such as NMC [86] have shown to suppress Mn dissolution hence improves the storage life, cycle life and/or capacity fading [87]. In particular, LBO glass was the first reported coating for $\mathrm{LiMn}_{2} \mathrm{O}_{4}$; it has a favorable ionic conductivity and can withstand oxidation at high potentials (i.e., $4 \mathrm{~V}$ ) as well as molten $\mathrm{LBO}$ glass has good wetting properties. The $\mathrm{LBO}$ glass surface treatment improves the storage performance, but has a detrimental effect on cycling life which is associated with the reduction of average $\mathrm{Mn}$ valence state on the surface by boron containing solid species [76]. On the other hand, $\mathrm{Al}$ doping of $\mathrm{LiMn}_{2} \mathrm{O}_{4}$ increased the average valance of $\mathrm{Mn}$, and showed enhanced cycling performance at high temperatures [83]. Li and $\mathrm{Al}$ co-doped manganese oxide spinel compounds prepared by polyvinyl pyrrolidone precursor method improved the initial discharge capacity and capacity retention [88]. $\mathrm{LiMn}_{2} \mathrm{O}_{4} / \mathrm{CNT}$ composites are also reported with improved capacity retention and high rate capability for flexible electronics applications [84]. More stable cathode materials such as $\mathrm{LiCoO}_{2}$ are also utilized as a barrier coating for $\mathrm{LiMn}_{2} \mathrm{O}_{4}$ [85]. A $5 \mathrm{~nm} \mathrm{LiCoO}_{2}$ coating prepared 
by micro-emulsion technique improved the cycle life and reduced the self-discharge of $\mathrm{LiMn}_{2} \mathrm{O}_{4}$; however, resulted in slight decrease in capacity of pristine $\mathrm{LiMn}_{2} \mathrm{O}_{4}$ due to Li storage inability of the $\mathrm{LiCoO}_{2}$ coating [85]. Synthesis of nano or submicron size $\mathrm{LiMn}_{2} \mathrm{O}_{4}$ particles and doping (i.e., partially substituting Mn site in $\left.\mathrm{LiMn}_{2} \mathrm{O}_{4}\right) \mathrm{LiMn}_{2} \mathrm{O}_{4}$ with transition and nontransition metals were shown to reduce the Mn dissolution upon cycling hence improved the cycle life of $\mathrm{LiMn}_{2} \mathrm{O}_{4}$ [88-94]. $\mathrm{LiMn}_{2} \mathrm{O}_{4}$ prepared by the one-pot molten salt method resulted in nano sized $(\sim 50 \mathrm{~nm})$ hollow spherical particles which showed improved capacity retention even at high C-rates (i.e., $96 \%$ retention at 5C rate) [89]. These nano sized spherical $\mathrm{LiMn}_{2} \mathrm{O}_{4}$ particles were also performed well at $50{ }^{\circ} \mathrm{C}$ which was associated with their high crystallinity and the presence of spherical particles [89]. In another study, Ru doped $\mathrm{LiMn}_{2-\mathrm{x}} \mathrm{Ru}_{\mathrm{x}} \mathrm{O}_{4}(\mathrm{x}=0.1$ and 0.25$)$ was shown to reduce the capacity fading as compared to undoped sample by mitigating the spinel-to-double-hexagonal transition at $4.5 \mathrm{~V}$, and due to the presence of $\mathrm{Ru}^{4+} \leftrightarrow \mathrm{Ru}^{5+}$ redox couple and better electronic conductivity of the $\mathrm{Ru}$ doped samples [92]. The other dopants studied for $\mathrm{LiMn}_{2} \mathrm{O}_{4}$ were $\mathrm{Co}, \mathrm{Cr}, \mathrm{Al}, \mathrm{Ni}$ and $\mathrm{Fe}[90,91,95,96]$. Sakunthala et al. obtained a notable $94 \%$ capacity retention at the end of 1000 cycles at $5 \mathrm{C}$ rate by the $\mathrm{Co}$ doped $\mathrm{LiMn}_{2} \mathrm{O}_{4}$ (i.e., $\left.\mathrm{Li}\left(\mathrm{Co}_{1 / 6} \mathrm{Mn}_{11 / 6}\right) \mathrm{O}_{4}\right)$. Most of the aforementioned coatings and dopants are inactive materials, and in practice, these materials lower the overall capacity of the spinel $\mathrm{LiMn}_{2} \mathrm{O}_{4}$ and increase the cost of material preparation. An alternative strategy is to mix the $\mathrm{LiMn}_{2} \mathrm{O}_{4}$ with a more stable cathode material such as NMC [86].

\subsection{Olivine, $\mathrm{LiMPO}_{4}(\mathrm{M}=\mathrm{Fe}, \mathrm{Co}, \mathrm{Mn}$ and Their Mixtures $)$}

Olive $\mathrm{LiFePO}_{4}$ stands out among cathode materials by its superior cycle life and intrinsic safety [97]. Additionally, $\mathrm{Fe}$ is one of the most abundant elements on Earth's crust (i.e., even less costly than $\mathrm{Mn}$ [63]), making $\mathrm{LiFePO}_{4}$ highly cost competitive. $\mathrm{LiFePO}_{4}$ has an average operating voltage of $3.4 \mathrm{~V}$ vs. $\mathrm{Li} / \mathrm{Li}^{+}$, and a specific capacity of $\sim 170 \mathrm{mAh} / \mathrm{g}$ corresponding to one $\mathrm{Li}$ per $\mathrm{LiFePO}_{4}$ formula unit. The enhanced cycle life and safety of $\mathrm{LiFePO}_{4}$ are associated with its lower operating voltage (i.e., $3.4 \mathrm{~V}$ ) compared to other cathode materials such as $\mathrm{LiCoO}_{2}$ (i.e., $4.2 \mathrm{~V}$ ) and $\mathrm{LiMn}_{2} \mathrm{O}_{4}$ (i.e., $4 \mathrm{~V}$ ). At such low potentials, non-aqueous electrolytes are highly stable. However, $\mathrm{LiFePO}_{4}$ has one-dimensional Li-ion diffusion channels leading to poor ionic conductivity, and it has an intrinsically low electronic conductivity. Moreover, $\mathrm{LiFePO}_{4}{ }^{\prime}$ s density is lower (i.e., $3.6 \mathrm{~g} / \mathrm{cm}^{3}$ ) than the layered oxides and spinels $\left(\sim 5 \mathrm{~g} / \mathrm{cm}^{3}\right)$ leading to poor volumetric energy density.

The low electronic conductivity of $\mathrm{LiFePO}_{4}$ can be enhanced by carbon coating [98] and by decreasing the $\mathrm{LiFePO}_{4}$ particle size [99], or both. Saranavan et al. showed that $\mathrm{LiFePO}_{4}$ nanoplates ( $\sim 30-40 \mathrm{~nm}$ along the b-axis) with a $5 \mathrm{~nm}$ amorphous carbon layer coating prepared by the solvothermal method significantly improved the high rate performance by effectively reducing the $\mathrm{Li}^{+}$diffusion length as compared to mesoporous spherical $\mathrm{LiFePO}_{4} / \mathrm{C}$ cathodes [100]. However, decreasing the particle size has a negative effect on tap density and accelerates the side reactions due to increased surface area; therefore, carbon coating is the most widely used method to improve the performance of $\mathrm{LiFePO}_{4}$. It was shown that, the quantity of carbon coating in $\mathrm{LiFePO}_{4}$ is not always proportional to the performance enhancement because several other parameters also play a key role in the performance of a carbon coated $\mathrm{LiFePO}_{4}$ such as structure of carbon [101], especially sp $2 / \mathrm{sp}^{3}$ and disordered/graphene (D/G) ratios [102], carbon source [103], carbon thickness [104], and processing conditions [105]. The single doping and co-doping of the carbon layer to improve the electronic conductivities are also explored. Phosphorus doped carbon layer on $\mathrm{LiFePO}_{4}$ has shown to decrease the charge transfer resistance significantly which is considered to be associated with the free carriers donated by the phosphorus. Additionally, phosphorus doped carbon layer improves the capacity and capacity retention at high $\mathrm{C}$ rates [106]. In another study, the $\mathrm{LiFePO}_{4}$ composite with boron and nitrogen co-doped carbon layers were synthesized by the ball milling process followed by calcination [107]. The sequence of doping shown to be critical (i.e., $\mathrm{N}+\mathrm{B}$ is preferred), and improvements in high-rate capacity are attributed to electron and hole type carriers donated by nitrogen and boron atoms, respectively [107]. Large scale and low-cost material preparation methods are critical for the higher 
penetration of $\mathrm{Li}$-ion batteries. $\mathrm{LiFePO}_{4}$ prepared by the carbothermal reduction method, which is suitable for large scale synthesis, showed almost no capacity fade for 400 cycles [108].

Carbon nanotubes (i.e., CNT) are excellent electronic conductors and have high surface area, and their tubular structure can enhance the overall electronic and ionic conductivity of the active cathode/anode materials by connecting the inert "dead" zones in these materials [109]. The schematic of the CNT dispersed in a porous $\mathrm{LiFePO}_{4}-\mathrm{CNT}$ composite is shown in Figure 10. The $\mathrm{LiFePO}_{4}-\mathrm{CNT}$ composite performed significantly better than the pristine $\mathrm{LiFePO}_{4}$ at both low and high $\mathrm{C}$ rates [109].

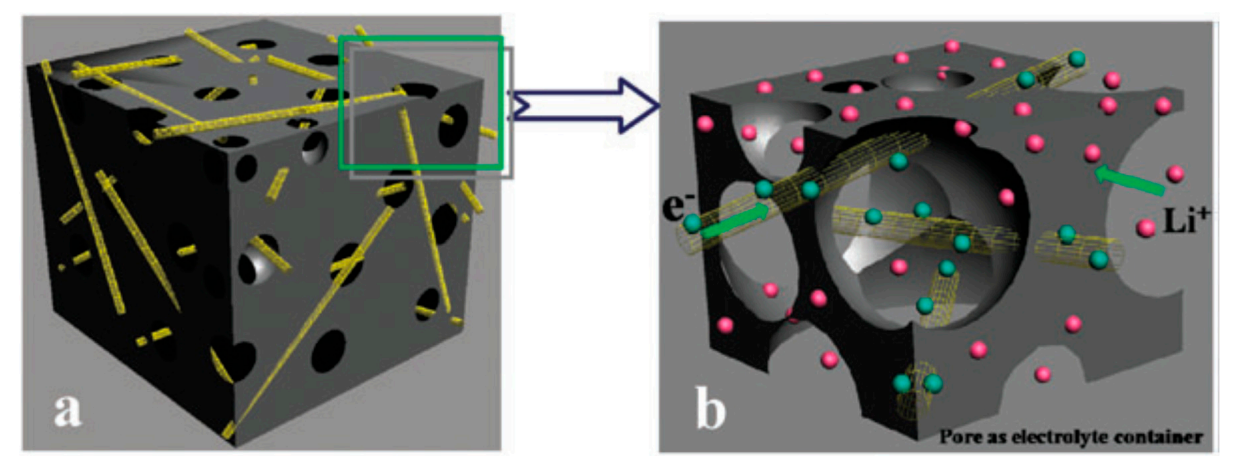

Figure 10. Schematic illustrations of the porous $\mathrm{LiFePO}_{4}-\mathrm{CNT}$ composite: (a) showing the corresponding electron transport and ion diffusion mechanisms; (b) is an enlarged zone from (a). Adapted with permission from [109], (c) Royal Society of Chemistry, 2010.

Another superior electronic conductor is the graphene. Utilizing graphene in $\mathrm{LiFePO}_{4}$ composites resulted in achieving near theoretical specific capacity (i.e., $170 \mathrm{mAh} / \mathrm{g}$ ), exceptional rate capability and improved the cycle life due to intimate contact between non-aqueous electrolyte and the $\mathrm{LiFePO}_{4}$ active materials as well as enhanced the charge and mass transfer $[110,111]$. The schematic of the graphene wrapped $\mathrm{LiFePO}_{4}$ particles are shown in Figure 11 [111]. Hu et al. reported that electrochemically exfoliated graphene wrapped commercial $\mathrm{LiFePO}_{4}$ particles can deliver $208 \mathrm{mAh} / \mathrm{g}$ capacity which is more than the theoretical capacity of $\mathrm{LiFePO}_{4}$. This extra capacity is attributed to the reversible redox reaction between $\mathrm{Li}$ ion in the electrolyte and the electrochemically exfoliated graphene sheets [112].

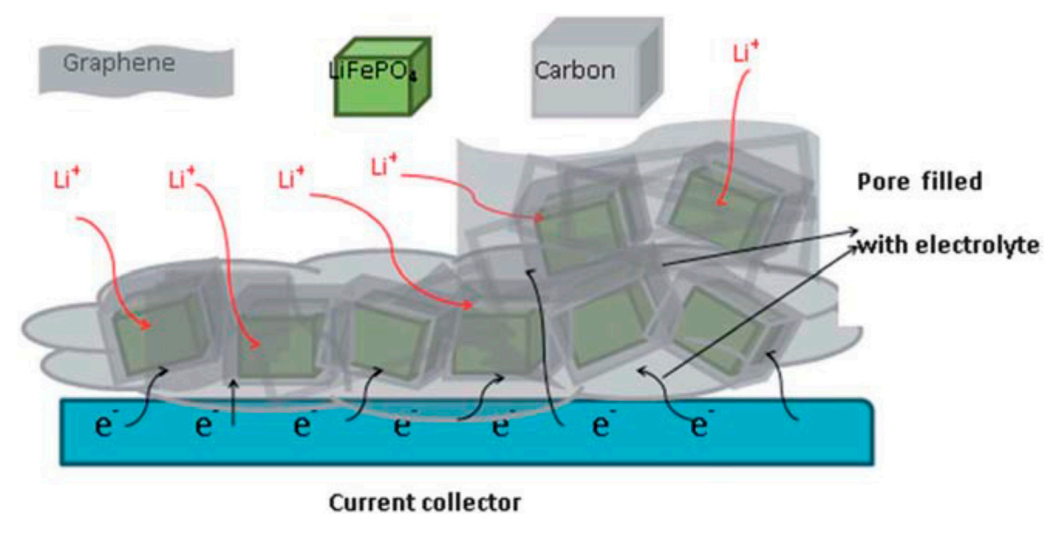

Figure 11. Schematic diagram of the graphene nanosheet $/ \mathrm{LiFePO}_{4}$ structure. Adapted with permission from [111], (c) Royal Society of Chemistry, 2012.

Further improvement in the performance of $\mathrm{LiFePO}_{4}$ was obtained by encapsulating one-dimensional $\mathrm{LiFePO}_{4}$ nanowires ( 20-30 nm) into CNTs (i.e., $\left.\mathrm{LiFePO}_{4} @ \mathrm{CNT}\right)$. These core-shell structures were synthesized by a sol-gel route followed by the post-heating treatment [113]. The dispersion of the CNT and its intimate contact with the $\mathrm{LiFePO}_{4}$ active material are critical for the performance enhancement [114]. By utilizing nitrogen doped CNT (i.e., N-CNT), instead of pristine 
$\mathrm{CNT}$, it is possible to facilitate the uniform dispersion of $\mathrm{CNT}$ in the $\mathrm{LiFePO}_{4}$ composite due to higher defect density and hydrophilic properties of $\mathrm{N}-\mathrm{CNTs}$. Additionally, nitrogen groups enhance the electronic conductivity of N-CNT as a result of increased electron density [114].

One of the limitations of $\mathrm{LiFePO}_{4}$ is its low operating voltage (i.e., $3.42 \mathrm{~V}$ ), which limits its energy density. It is possible to push the operating voltage to higher voltages (i.e., $4-4.2 \mathrm{~V}$ ) using vanadium-based cathodes such as $\mathrm{LiVPO}_{4} \mathrm{~F}$ and $\mathrm{LiVOPO}_{4}$ [115-121]. Novel porous materials such as metal-organic frameworks (MOF) were also studied as electrode materials for Li-ion batteries [118,119,122-124]. Metal organic phosphate open frameworks (MOPOF) and their reduced graphene oxide nanocomposite derivatives showed promising Li storage, but further work is required to improve their rate capability and cycle life $[118,119]$.

\section{Anode Materials}

\subsection{Carbon Based Anodes}

Carbon based anode materials are the industry standard in Li-ion batteries, and graphitic carbon is the dominant one due to its favorable electrochemical properties (i.e., low and near flat operating voltage of $\sim 0.25 \mathrm{~V}$ vs. $\mathrm{Li} / \mathrm{Li}^{+}$), low cost, and chemical and mechanical stability $[125,126]$. Graphite has a theoretical capacity of $372 \mathrm{mAh} / \mathrm{g}$ with the stoichiometry of $\mathrm{LiC}_{6}$. Non-graphitic carbons such as hard carbons have higher specific capacity and cycle life, good rate capabilities and lower cost of production; however, they suffer from low density and larger irreversible capacity and hysteresis in the voltage profile [127].

The metal-carbon composites have been extensively studied to improve the performance of carbon anode materials [128-135]. The composite anodes, in general, showed improved performance than simple mechanical mixing of the metals with the anode materials [125]. The chemically deposited $\mathrm{Ag}$ on graphite improved the cycle life, which was attributed to the enhanced electron conduction between graphite particles due to low electrical resistance of Ag. Additionally, the capacity of the Ag-graphite composite cathode was superior to the graphite cathode alone since Ag can form LiAg alloy upon interaction with Li [128]. Moreover, Ag deposited graphite was shown to be more resistant to humidity (i.e., $1000 \mathrm{ppm}$ ) which is beneficial for easy manufacturing of Li-ion batteries $[129,130]$. The microencapsulation of graphite with nanosized Ni showed improvement in initial charge-discharge performance, Coulombic efficiency and cycle life. The proposed mechanism for the improvement in the initial charge-discharge behavior (i.e., decrease in irreversible capacity) was the passivation of the graphite edge surfaces by $\mathrm{Ni}$ deposition which in return reduces the highly active edge surface area that is exposed to the electrolyte, and makes the edge surfaces less permeable to the solvated $\mathrm{Li}$ ions $[131,132]$. Similar effects were also observed for $\mathrm{Cu}$ deposited natural graphite, in addition to the suppression of electrolyte decomposition and solvated Li ion co-intercalation, improvement in high rate capability was reported due to enhanced charge-transfer properties [133]. The Al deposition of natural graphite improved the cycle life and rate capability remarkably due to decreased charge-transfer resistance during cycling [134]. The other metals studied for metal-graphite composites include $\mathrm{Au}$, $\mathrm{Bi}, \mathrm{In}, \mathrm{Pb}, \mathrm{Pd}, \mathrm{Sn}$ and $\mathrm{Zn}$, and all these metal coatings, which were prepared by vacuum evaporation technique, improved the rate capability [135]. The rate capability was found to be dependent on the film thickness, too thick coatings limit the Li mobility hence reduces the rate capability.

Carbon coating is another strategy to improve the electrochemical performance of the graphite [136-139]. One of the methods to enhance the low temperature performance of Li-ion batteries is to utilize propylene carbonate (i.e., $\mathrm{PC}$, melting point $=-49^{\circ} \mathrm{C}$ ) based solvents instead of ethylene carbonate (i.e., EC, melting point $=38^{\circ} \mathrm{C}$ ) based ones. However, it is well known that PC decomposes on the graphite surface; therefore, cannot form a stable solid electrolyte interphase (SEI) layer on the graphite surface which leads to diminished cycle life [140]. The studies conducted on carbon coated graphite prepared by thermal and chemical vapor decomposition techniques showed that Coulombic efficiency can be improved significantly since carbon coating acts as a buffer zone 
between graphite and the PC based electrolyte, and leads to compact and thinner SEI layer as shown in Figure 12 [137-139]. If carbon coated graphite anode is utilized in Li-ion battery manufacturing, high rolling and calendaring pressures should be avoided since high pressures can destroy the carbon coating [137]. The carbon coating also stores Li hence does not adversely affect the specific capacity of the graphite [139].

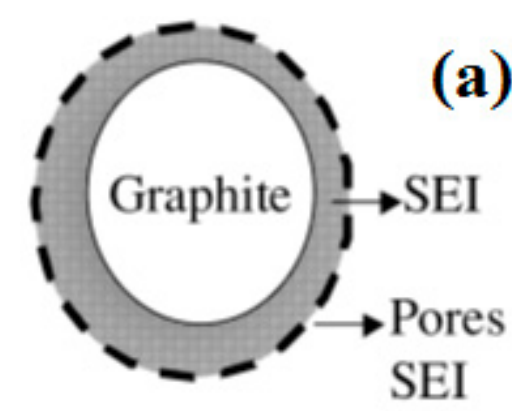

Pristine graphite

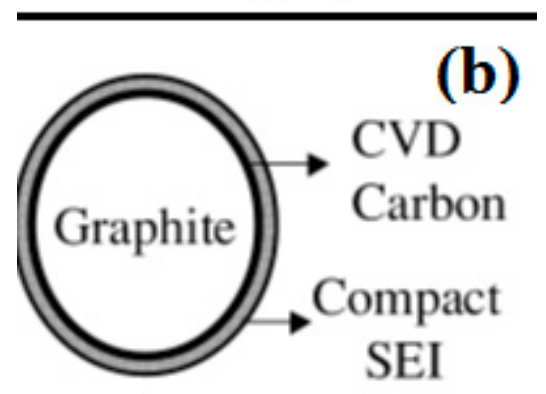

\section{Carbon coated graphite}

Figure 12. Schematic of the SEI layer on (a) pristine and (b) carbon coated graphite. Adapted with permission from [138], (c) Elsevier, 2001.

Another promising approach to protect pristine graphite from PC based solvents is rolling graphite flakes into spherical shape, and then coating with carbon [136]. The spherical shape mitigates the high orientation of the graphite flakes when coated over a current collector, hence improves the Li ion diffusion rate. Additionally, spherical graphite formed by concentric alignment of multiple graphene layers reduces the number of edge planes exposed to solvents (i.e., PC); in other words, inert basal planes are mostly exposed to PC instead of active edge planes which is favorable to improve the Coulombic efficiency [136].

\subsection{Alloy Anodes}

To meet the battery system targets set by the U.S. DOE given in Table 2, it is necessary to improve the gravimetric and volumetric energy density of the batteries significantly which can only be achieved by developing novel materials with enhanced Li storage properties. To achieve this goal, one of the alternatives is to replace graphite, either completely or partially, with alloy anode materials. The most promising and well-studied alloy anodes are presented in Figure 13. 


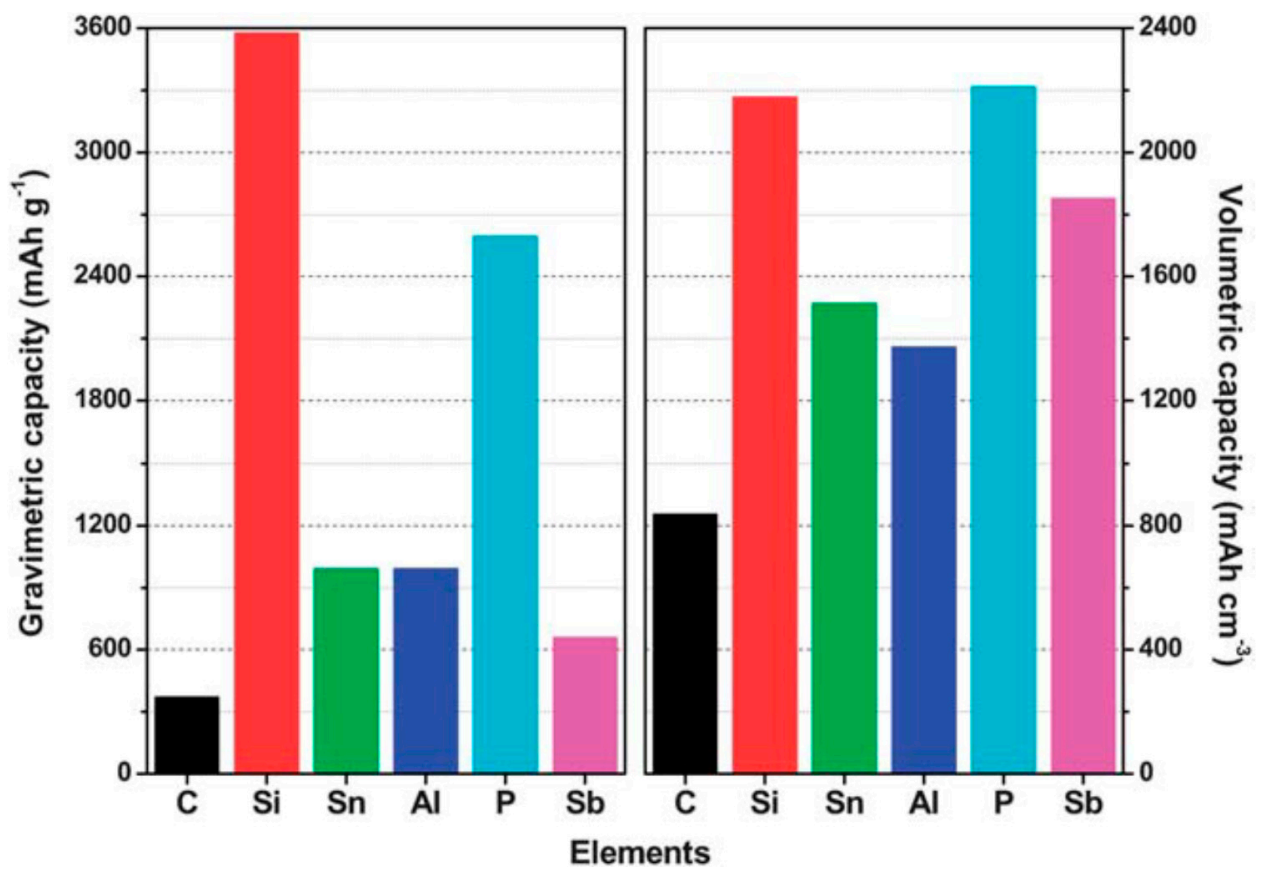

Figure 13. Theoretical gravimetric and volumetric capacities of $\mathrm{C}\left(\mathrm{LiC}_{6}\right), \mathrm{Si}\left(\mathrm{Li}_{3.75} \mathrm{Si}\right), \mathrm{Sn}\left(\mathrm{Li}_{4.4} \mathrm{Sn}\right), \mathrm{Al}$ (LiAl), P ( $\left.\mathrm{Li}_{3} \mathrm{P}\right)$ and $\mathrm{Sb}\left(\mathrm{Li}_{3} \mathrm{Sb}\right)$. Adapted with permission from [141], (C) Royal Society of Chemistry, 2011.

One should note that, currently Li metal anode is not considered to be a viable candidate due to dendrite formation and the accompanying safety concerns [142]. Among different alloy anodes given in Figure 13, Si and Sn have attracted the most attention due their superior gravimetric and volumetric capacity. However, these alloy anodes experience large volume change ( $>300 \%)$ upon $\mathrm{Li}$ de-/intercalation which causes particle cracking and pulverization upon cycling which leads to poor cycle life. Additionally, this large volume change during cycling prevents the formation of a stable SEI layer on the alloy anodes, which continuously consumes Li ions, and results in low Coulombic efficiency. One simple but effective strategy to suppress the rapid deterioration of cycle life in Si anodes is to prepare a composite anode with low $\mathrm{Si}$ (i.e., $\mathrm{Si}<33 \mathrm{wt} \%$ ) and high binder (i.e., 33-56 wt \%) content [143]. However, high inactive mass in this composite cathode severely limits the specific capacity (i.e., $250 \mathrm{mAh} / \mathrm{g}$ after 400 cycles).

Another approach is to partially replace graphite with $\mathrm{Si}$. The graphite-Si composite anodes with carbon coating showed better performance than $\mathrm{Si}$ alone, but quick degradation of cycle life is still a concern in these type of materials [144,145]. The carbon and metal coating techniques were also applied to improve the cycle life and Coulombic efficiency of Si anodes $[146,147]$. These coatings reduce the electrolyte decomposition on Si anodes by creating a buffer zone between the electrolyte and $\mathrm{Si}$, but due to significant volume change of $\mathrm{Si}$ anode, the carbon coating loses its structural integrity by cycling, and fresh $\mathrm{Si}$ surfaces are exposed to electrolyte eventually. In another study, nanocrystalline Si particles of $20-80 \mathrm{~nm}$ that were encapsulated in a carbon aerogel showed a stable reversible capacity of $1450 \mathrm{mAh} / \mathrm{g}$ for 50 cycles [147]. The carbon aerogel works as a cushion during the expansion-contraction of the nanocrystalline Si particles, and maintains the three dimensional electrical network; this way, Si particles stay in physical contact with the carbon matrix at all times. More recent studies on Si anodes concentrated on minimizing the Si surface area exposed to electrolyte by encapsulating single Si nanoparticle in a carbon shell (i.e., yolk-shell design) which has enough void space to accommodate significant volume changes during de-/lithiation of Si [148]. This strategy minimizes the carbon shell deformation upon cycling, hence helps with obtaining a stable SEI layer over the carbon shell. This Si-carbon composite showed a reversible capacity of $1500 \mathrm{mAh} / \mathrm{g}$ at $1 \mathrm{C}$ rate after the initial formation cycles, and kept $74 \%$ of its initial capacity after 1000 cycles. In a similar 
approach, inspired by a pomegranate fruit, carbon coated Si nanoparticles are further encapsulated in a thick secondary carbon layer as shown in Figure 14 [149]. As a result, the SEI layer mostly forms on this secondary carbon layer (i.e., lower surface area) instead of the individual Si nanoparticles (i.e., higher surface area), Figure 14c. This pomegranate inspired Si-carbon composite anode showed $97 \%$ percent capacity retention (i.e., $1160 \mathrm{mAh} / \mathrm{g}$ ) after 1000 cycles.

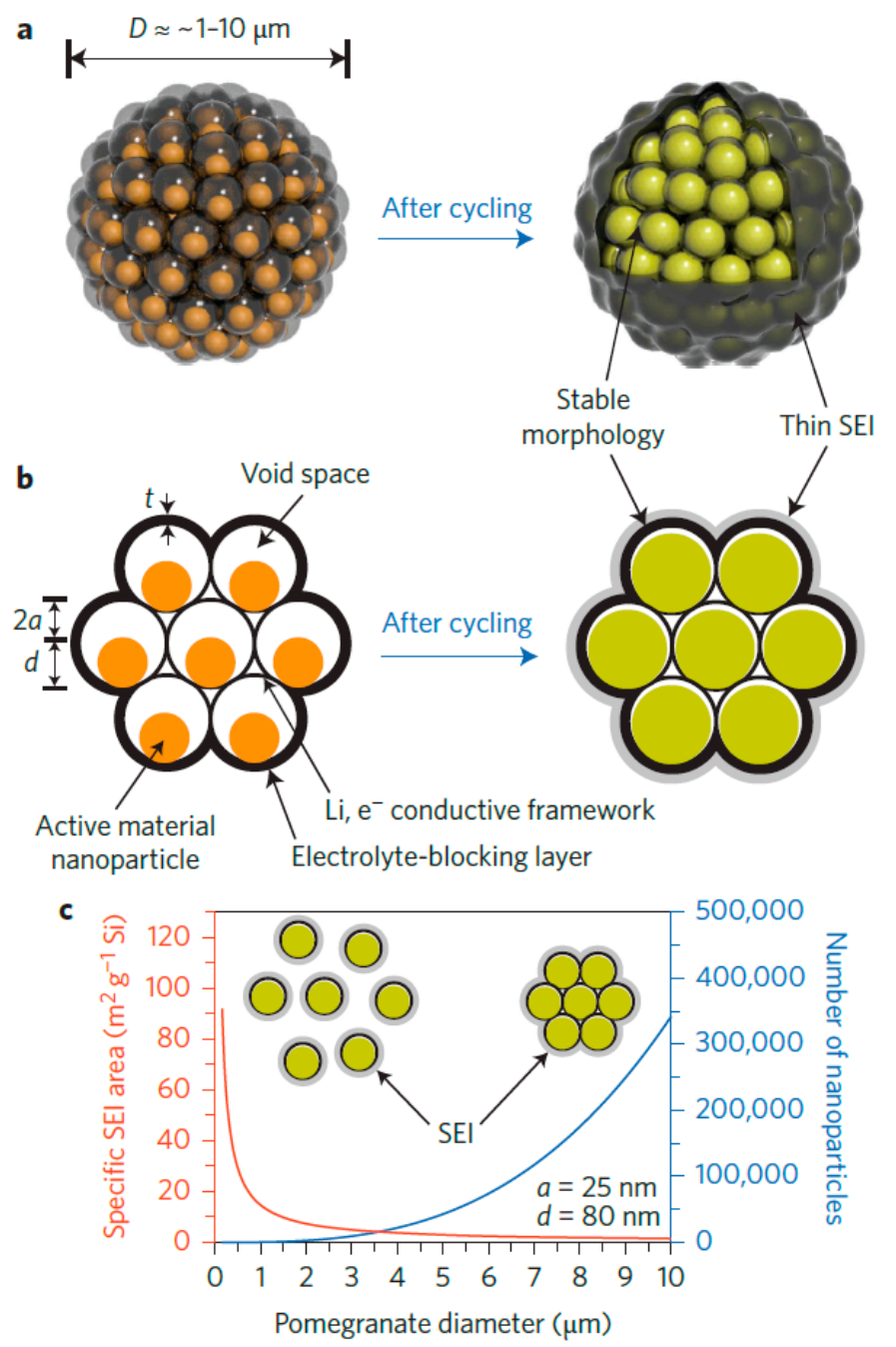

Figure 14. The schematic of the pomegranate-inspired Si anode design in (a) 3D and (b) 2D before and after cycling (in the lithiated state); (c) The variation of the specific SEI area and the number of primary nanoparticles in one pomegranate particle versus its diameter. Adapted with permission from [149], (c) Nature Publishing Group, 2014.

\section{Binder}

Binder is one of the inactive components in a Li-ion battery electrode, but its role is critical for proper operation of the Li-ion batteries. Binder serves as a polymeric matrix that connects active materials to each other and to the current collector in a composite Li-ion battery electrode, and accommodates volume changes due to de-/lithiation of active materials during battery operation. An ideal binder should have: (a) high binding strength, (b) favorable mechanical properties to accommodate volume changes, (c) high electronic conductivity, (d) optimal porous structure for high ionic conductivity and (e) chemical inertness [16,150]. Currently, polyvinylidene fluoride (PVDF) is the most common binder despite its shortcomings. PVDF is not conductive and does not store $\mathrm{Li}$ hence considered as an inactive material. Several different electroactive polymers 
such as polyaniline and polypyrrole were proposed to replace PVDF. These multifunctional binders improved the rate capability and cycle life of the $\mathrm{LiFePO}_{4}$ which has an intrinsically poor electronic conductivity [151-154]. The polyaniline binder also improved the irreversible capacity loss during the first cycle in a graphite anode [155]. As discussed earlier, the alloy anodes show significant volume change upon de-/lithiation; therefore, an ideal binder should be highly flexible and mechanically robust to keep active materials together during cycling. Different composite elastomeric binders were developed for Si alloy anodes [156-158]. The PVDF-tetrafluoroethylene-propylene (PVDF-TFE-P) binder can be extended to $100 \%$ strain, whereas PVDF can only be extended to $10 \%$ strain. The PVDF-TFE-P binder enhanced the cycle life of a- $\mathrm{Si}_{0.64} \mathrm{Sn}_{0.36}$ alloy anode reasonably [157]. Another promising elastomeric binder is styrene-butadiene-rubber (SBR) and sodium-carboxyl-methylcellulose (SCMC) composite. As compared to PVDF, SBR + SCMC binder showed smaller moduli, a larger maximum elongation, and a stronger adhesion strength hence better cycle life in Si alloy anodes [158]. Crosslinking is an effective strategy to improve the mechanical properties of polymeric binders. By crosslinking poly(acrylic acid) with SCMC, Koo et al. obtained a capacity of $2000 \mathrm{mAh} / \mathrm{g}$ for Si anode after 100 cycles [159]. Recently, a new type of binder, hyperbranched $\beta$-cyclodextrin polymer and a dendritic gallic acid cross-linker with six adamantane units, for $\mathrm{Si}$ anodes based on "dynamic crosslinking" method was developed as shown in Figure 15 [160]. The dynamic crosslinking refers to supramolecular host-guest interactions. The distinctive feature of this polymer is that it can restore the broken connections between polymer chains during cycling; therefore, it can be considered as a self-healing binder. The $\mathrm{Si}$ anode based on this novel composite binder retained $90 \%$ of its initial capacity after 150 cycles ( 1550 mAh/g).

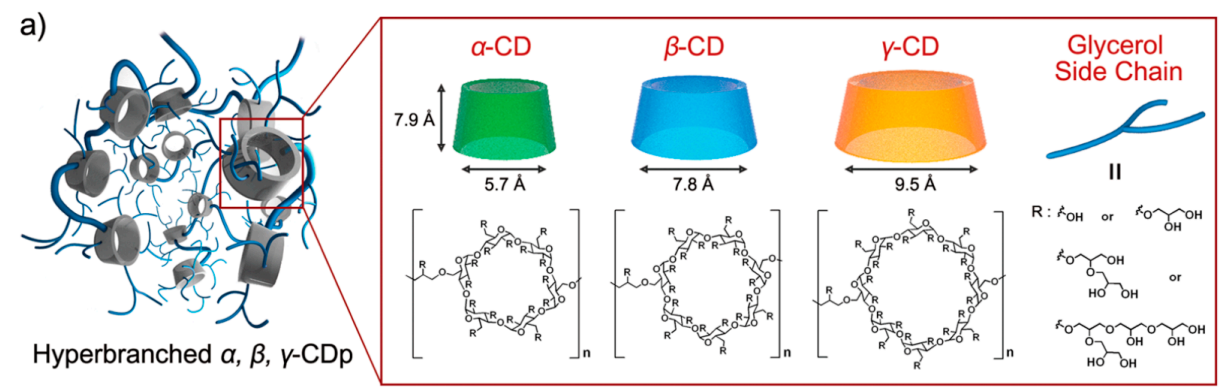

b)

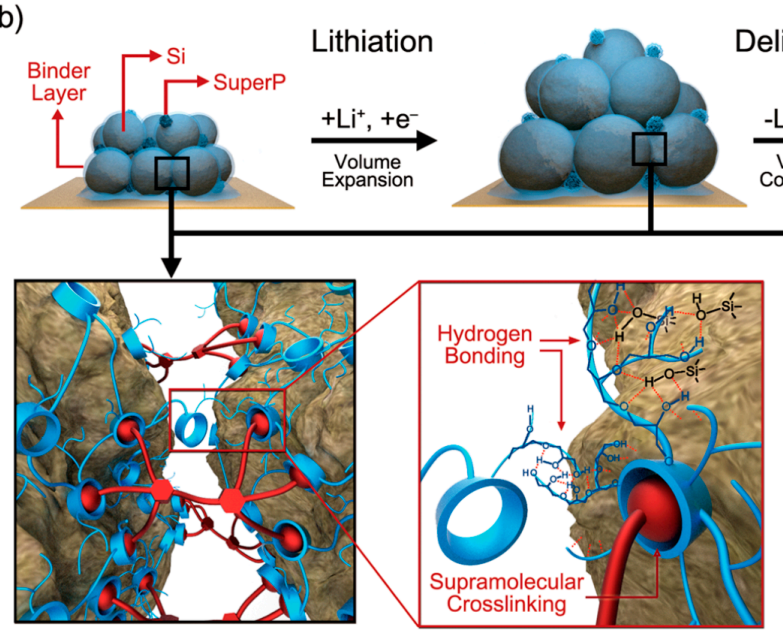

Delithiation
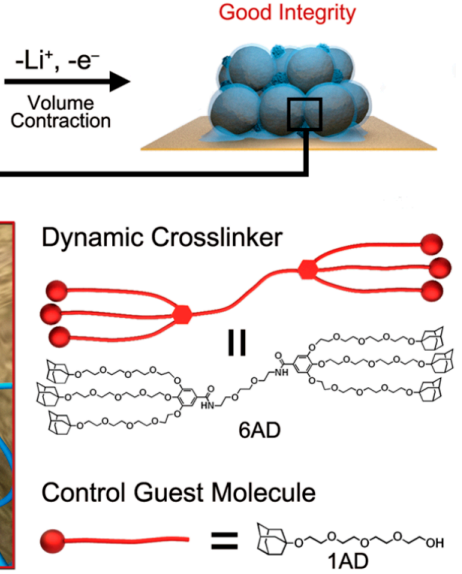

Figure 15. (a) Schematic and structures of hyperbranched R-, $\beta$-, and $\gamma$-cyclodextrin polymer (CDp); (b) Dynamic cross-linking mechanism of $\beta$-CDp and 6 adamantane (AD) in an electrode matrix along with schematic and structures of guest molecules incorporating AD moiety. Adapted with permission from [160], @ American Chemical Society, 2015. 
Separator

Separator is another inactive component in Li-ion batteries, but it plays a critical role in the operation and safety of such batteries. Separator physically separates the anode and cathode to prevent the electrical short circuit, while allowing Li-ion diffusion due to its porous structure in between the anode and cathode during cycling of a cell. Therefore, an ideal separator should be a good electronic insulator, mechanically robust, chemically inert under the operating conditions of the battery, and should have good wettability in non-aqueous liquid electrolytes [18]. The most common types of Li-ion battery separators are microporous and non-woven separators, former being the dominant in the Li-ion battery market [161]. The microporous separators are mainly made of polyolefins such as polyethylene (PE) and polypropylene (PP). The scanning electron microscope (SEM) images of a multilayered composite separator manufactured by Celgard ${ }^{\mathrm{TM}}$ are given in Figure 16. The multilayer structure $(\mathrm{PP} / \mathrm{PE} / \mathrm{PP})$ is instrumental in preventing the thermal runaway of the Li-ion battery via thermal shut-down mechanism [161].
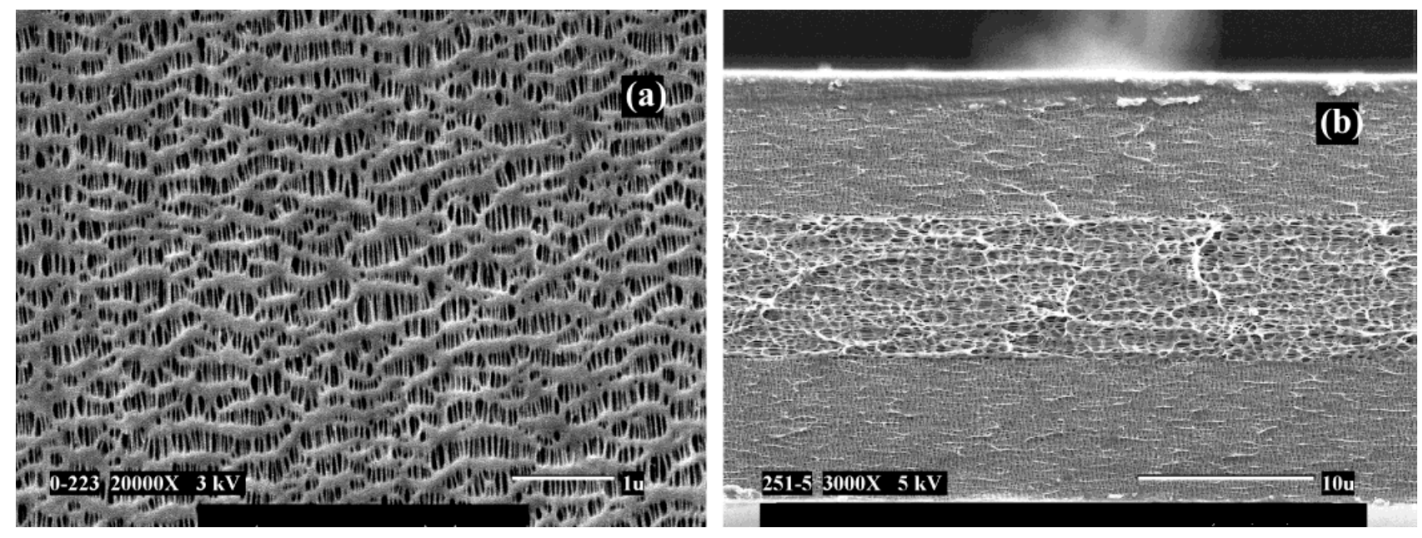

Figure 16. SEM images of Celgard 2325 (PP/PE/PP) separator used in lithium-ion batteries: (a) surface SEM and (b) cross-section SEM images. Adapted with permission from [161], (C) American Chemical Society, 2004.

The thermal stability, wettability and mechanical properties of the separators can be improved by surface coating, grafting and blending techniques [18]. The surface coating of the microporous separators with high temperature polymers such as polyimide, inorganic nanoparticles such as $\mathrm{Al}_{2} \mathrm{O}_{3}$ and $\mathrm{SiO}_{2}$, or the combination of polymers and inorganic nanoparticles have shown to reduce the thermal shrinkage, and improved the mechanical properties and wettability of the separators [162-165]. It is important to note that surface coating creates an additional layer on the separator, which may limit the Li-ion diffusion rate hence the performance (i.e., cycle life and rate capability) of the cell. Although the surface coating is effective in improving the aforementioned properties of the separator, uniformity, thickness and adhesion of the coated layer are of concern in practical applications [18]. To circumvent these issues associated with the surface coating technique, surface grafting can be utilized. Unlike coting, grafting results in the permanent attachment of the desired functional groups via covalent bonding. The surface grafting can be achieved by UV-irradiation, plasma treatment and high energy radiation methods [18]. The siloxane grafted PE separator prepared by electron beam irradiation showed enhanced ionic conductivity and wettability as well as improved cycle life at high voltage operating conditions [166]. Similar results were obtained for glycidyl methacrylate grafted PE separator [167].

Traditionally, non-woven separators are not considered to be competitive with the microporous separators due to their large pore structure and difficulty in manufacturing them thin $(<25 \mu \mathrm{m})$ with the desired mechanical properties $[18,161]$. One of the promising non-woven (polyethylene terephthalate) separators with ceramic coating (i.e., $\mathrm{Al}_{2} \mathrm{O}_{3}$ ) on both sides (i.e., Degussa-Separion ${ }^{\mathrm{TM}}$ ) is shown in 
Figure 17. This commercially available separator have good wettability, superior chemical resistance and very low shrinkage at high temperatures [18].

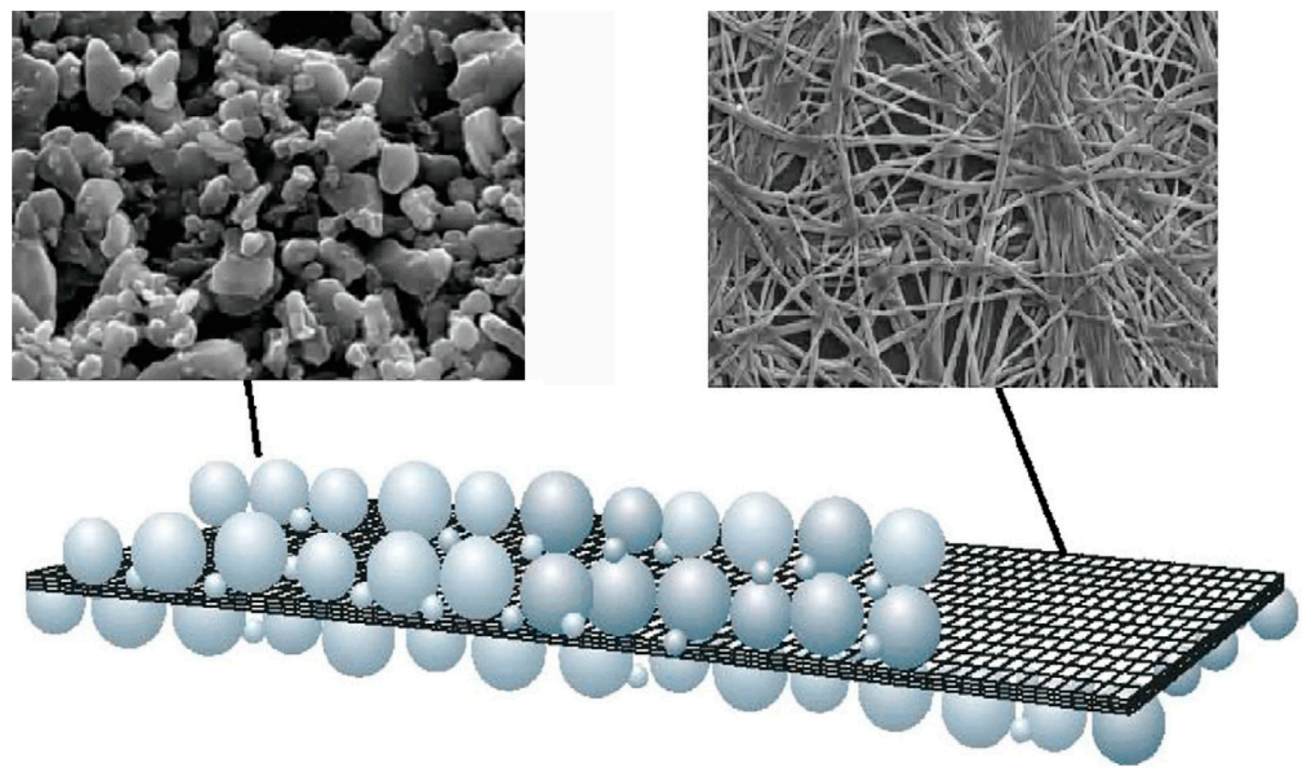

Figure 17. Schematic structure of the Degussa-Separion ${ }^{\mathrm{TM}}$ separators. Adapted with permission from [168], @ Elsevier, 2007.

\section{Conclusions}

Rechargeable batteries play a critical role in portable electronics, transportation, back-up power and load-leveling applications. Currently, lead acid and Li-ion chemistries are the most important types of rechargeable batteries. The Li-ion chemistry is expected to play a bigger role in the future due to its superior gravimetric and volumetric densities as compared to other battery chemistries. Additionally, the cost of Li-ion batteries continues to drop due to engineering improvements and materials advancements. The nanocomposite materials are at the center of the material developments in cathode, anode, binder and separator of Li-ion batteries as discussed in this article. Particularly, nanocomposite materials can improve the safety, cycle-life, rate capability and specific capacity of Li-ion batteries. It should be noted that further improvements in the nanocomposites and their manufacturing processes are required to reach the U.S. DOE targets for energy density and cost of battery systems.

Acknowledgments: The authors greatly acknowledge the financial support from the Texas A\&M University-Kingsville.

Author Contributions: Dervis Emre Demirocak conceived this work and wrote the manuscript. Sesha S. Srinivasan and Elias K. Stefanakos proofread the manuscript.

Conflicts of Interest: The authors declare no conflicts of interest.

\section{References}

1. Chen, H.; Cong, T.N.; Yang, W.; Tan, C.; Li, Y.; Ding, Y. Progress in electrical energy storage system: A critical review. Prog. Nat. Sci. 2009, 19, 291-312. [CrossRef]

2. Weinert, J.X.; Burke, A.F.; Wei, X. Lead-acid and lithium-ion batteries for the Chinese electric bike market and implications on future technology advancement. J. Power Sources 2007, 172, 938-945. [CrossRef]

3. Frost \& Sullivan. Frost \& Sullivan Research Service-World Lithium-ion Battery Market. 2009. Available online: http:/ / www.frost.com/prod/servlet/report-brochure.pag?id=N76F-27-00-00-00\#Further (accessed on 10 May 2017). 
4. Ceraolo, M.; Huria, T.; Pede, G.; Vellucci, F. Lithium-ion starting-lighting-ignition batteries: Examining the feasibility. In Proceedings of the 2011 IEEE Vehicle Power and Propulsion Conference (VPPC), Chicago, IL, USA, 6-9 September 2011.

5. Doeff, M.M. Battery cathodes. In Batteries for Sustainability; Springer: New York, NY, USA, 2013; pp. 5-49.

6. Battery University. What's the Best Battery? Available online: http://batteryuniversity.com/learn/archive/ whats_the_best_battery (accessed on 9 May 2017).

7. Zu, C.X.; Li, H. Thermodynamic analysis on energy densities of batteries. Energy Environ. Sci. 2011, 4, 2614-2624. [CrossRef]

8. U.S. Department of Energy. The EV Everywhere Grand Challenge: Road to Success; U.S. Department of Energy: Washington, DC, USA, 2014. Available online: http://energy.gov/sites/prod/files/2016/05/f31/ eveverywhere_road_to_success.pdf (accessed on 11 May 2017).

9. Voelcker, J. Electric-car battery costs: Tesla $\$ 190$ per kwh for pack, GM \$145 for cells. Green Car Reports. 28 April 2016. Available online: http:/ / www.greencarreports.com/news/1103667_electric-car-battery-coststesla-190-per-kwh-for-pack-gm-145-for-cells (accessed on 16 June 2017).

10. Nykvist, B.; Nilsson, M. Rapidly falling costs of battery packs for electric vehicles. Nat. Clim. Chang. 2015, 5, 329-332. [CrossRef]

11. Nitta, N.; Wu, F.; Lee, J.T.; Yushin, G. Li-ion battery materials: Present and future. Mater. Today 2015, 18, 252-264. [CrossRef]

12. Fergus, J.W. Recent developments in cathode materials for lithium ion batteries. J. Power Sources 2010, 195, 939-954. [CrossRef]

13. Tarascon, J.; Guyomard, D. The $\mathrm{Li}_{1+x} \mathrm{Mn}_{2} \mathrm{O}_{4} / \mathrm{C}$ rocking-chair system: A review. Electrochim. Acta 1993, 38, 1221-1231. [CrossRef]

14. Reddy, M.; Subba Rao, G.; Chowdari, B. Metal oxides and oxysalts as anode materials for Li ion batteries. Chem. Rev. 2013, 113, 5364-5457. [CrossRef] [PubMed]

15. Goriparti, S.; Miele, E.; De Angelis, F.; Di Fabrizio, E.; Zaccaria, R.P.; Capiglia, C. Review on recent progress of nanostructured anode materials for Li-ion batteries. J. Power Sources 2014, 257, 421-443. [CrossRef]

16. Lestriez, B. Functions of polymers in composite electrodes of lithium ion batteries. C. R. Chim. 2010, 13, 1341-1350. [CrossRef]

17. Chou, S.L.; Pan, Y.; Wang, J.Z.; Liu, H.K.; Dou, S.X. Small things make a big difference: Binder effects on the performance of Li and Na batteries. Phys. Chem. Chem. Phys. 2014, 16, 20347-20359. [CrossRef] [PubMed]

18. Zhang, H.; Zhou, M.Y.; Lin, C.E.; Zhu, B.K. Progress in polymeric separators for lithium ion batteries. RSC Adv. 2015, 5, 89848-89860. [CrossRef]

19. Wakihara, M. Recent developments in lithium ion batteries. Mater. Sci. Eng. R Rep. 2001, 33, $109-134$. [CrossRef]

20. Winter, M.; Brodd, R.J. What are batteries, fuel cells, and supercapacitors? Chem. Rev. 2004, 104, 4245-4270. [CrossRef] [PubMed]

21. Hu, M.; Pang, X.; Zhou, Z. Recent progress in high-voltage lithium ion batteries. J. Power Sources 2013, 237, 229-242. [CrossRef]

22. MIT Electric Vehicle Team. A Guide to Understanding Battery Specifications. Available online: http://web.mit.edu/evt/summary_battery_specifications.pdf (accessed on 7 May 2017).

23. Reddy, M.V.; Wei Wen, B.L.; Loh, K.P.; Chowdari, B.V.R. Energy storage studies on $\mathrm{InVO}_{4}$ as high performance anode material for Li-ion batteries. ACS Appl. Mater. Interfaces 2013, 5, 7777-7785. [CrossRef] [PubMed]

24. Reddy, M.; Subba Rao, G.; Chowdari, B. Preparation and characterization of $\mathrm{LiNi}_{0.5} \mathrm{Co}_{0.5} \mathrm{O}_{2}$ and $\mathrm{LiNi}_{0.5} \mathrm{Co}_{0.4} \mathrm{Al}_{0.1} \mathrm{O}_{2}$ by molten salt synthesis for $\mathrm{Li}$ ion batteries. J. Phys. Chem. C 2007, 111, 11712-11720.

25. Levi, M.; Aurbach, D. Impedance of a single intercalation particle and of non-homogeneous, multilayered porous composite electrodes for Li-ion batteries. J. Phys. Chem. B 2004, 108, 11693-11703. [CrossRef]

26. Xu, K. Nonaqueous liquid electrolytes for lithium-based rechargeable batteries. Chem. Rev. 2004, 104, 4303-4418. [CrossRef] [PubMed]

27. Nishi, Y. Lithium ion secondary batteries; past 10 years and the future. J. Power Sources 2001, 100, 101-106. [CrossRef]

28. Mizushima, K.; Jones, P.; Wiseman, P.; Goodenough, $\mathrm{J} \mathrm{Li}_{\mathrm{x}} \mathrm{CoO}_{2}(0<\mathrm{x}<1)$ : A new cathode material for batteries of high energy density. Solid State Ion. 1981, 3, 171-174. [CrossRef] 
29. Mizushima, K.; Jones, P.; Wiseman, P.; Goodenough, $\mathrm{J}^{\mathrm{Li}} \mathrm{Li}_{\mathrm{x}} \mathrm{CoO}_{2}(0<\mathrm{x}<-1)$ : A new cathode material for batteries of high energy density. Mater. Res. Bull. 1980, 15, 783-789. [CrossRef]

30. Zou, H.; Gratz, E.; Apelian, D.; Wang, Y. A novel method to recycle mixed cathode materials for lithium ion batteries. Green Chem. 2013, 15, 1183-1191. [CrossRef]

31. Thackeray, M.M.; David, W.I.F.; Bruce, P.G.; Goodenough, J.B. Lithium insertion into manganese spinels. Mater. Res. Bull. 1983, 18, 461-472. [CrossRef]

32. Padhi, A.K.; Nanjundaswamy, K.; Goodenough, J. Phospho-olivines as positive-electrode materials for rechargeable lithium batteries. J. Electrochem. Soc. 1997, 144, 1188-1194. [CrossRef]

33. Brodd, R.J. Batteries for Sustainability: Selected Entries from the Encyclopedia of Sustainability Science and Technology; Springer: New York, NY, USA, 2013.

34. Cho, J.; Kim, Y.J.; Park, B. Novel $\mathrm{LiCoO}_{2}$ cathode material with $\mathrm{Al}_{2} \mathrm{O}_{3}$ coating for a Li ion cell. Chem. Mater. 2000, 12, 3788-3791. [CrossRef]

35. Chen, Z.; Dahn, J. Methods to obtain excellent capacity retention in $\mathrm{LiCoO}_{2}$ cycled to 4.5 V. Electrochim. Acta 2004, 49, 1079-1090. [CrossRef]

36. Chebiam, R.; Kannan, A.; Prado, F.; Manthiram, A. Comparison of the chemical stability of the high energy density cathodes of lithium-ion batteries. Electrochem. Commun. 2001, 3, 624-627. [CrossRef]

37. Cho, J.; Kim, G. Enhancement of thermal stability of $\mathrm{LiCoO}_{2}$ by $\mathrm{LiMn}_{2} \mathrm{O}_{4}$ coating. Electrochem. Solid State Lett. 1999, 2, 253-255. [CrossRef]

38. Cho, J.; Kim, C.S.; Yoo, S.I. Improvement of structural stability of $\mathrm{LiCoO}_{2}$ cathode during electrochemical cycling by sol-gel coating of $\mathrm{SnO}_{2}$. Electrochem. Solid State Lett. 2000, 3, 362-365. [CrossRef]

39. Chen, Z.; Dahn, J. Effect of a $\mathrm{ZrO}_{2}$ coating on the structure and electrochemistry of $\mathrm{Li}_{\mathrm{x}} \mathrm{CoO}_{2}$ when cycled to 4.5 V. Electrochem. Solid State Lett. 2002, 5, A213-A216. [CrossRef]

40. Wang, Z.; Wu, C.; Liu, L.; Wu, F.; Chen, L.; Huang, X. Electrochemical evaluation and structural characterization of commercial $\mathrm{LiCoO}_{2}$ surfaces modified with $\mathrm{MgO}$ for lithium-ion batteries. J. Electrochem. Soc. 2002, 149, A466-A471. [CrossRef]

41. Hong, W.; Ming-Cai, C. Modification of $\mathrm{LiCoO}_{2}$ by surface coating with $\mathrm{MgO} / \mathrm{TiO}_{2} / \mathrm{SiO}_{2}$ for high-performance lithium-ion battery. Electrochem. Solid-State Lett. 2006, 9, A82-A85. [CrossRef]

42. Chen, Z.; Qin, Y.; Amine, K.; Sun, Y.K. Role of surface coating on cathode materials for lithium-ion batteries. J. Mater. Chem. 2010, 20, 7606-7612. [CrossRef]

43. Cho, J.; Lee, J.G.; Kim, B.; Park, B. Effect of $\mathrm{P}_{2} \mathrm{O}_{5}$ and $\mathrm{AlPO}_{4}$ coating on $\mathrm{LiCoO}_{2}$ cathode material. Chem. Mater. 2003, 15, 3190-3193. [CrossRef]

44. Lee, J.G.; Kim, T.G.; Park, B. Metal-phosphate coating on $\mathrm{LiCoO}_{2}$ cathodes with high cutoff voltages. Mater. Res. Bull. 2007, 42, 1201-1211. [CrossRef]

45. Kim, J.; Noh, M.; Cho, J.; Kim, H.; Kim, K.B. Controlled nanoparticle metal phosphates (Metal = Al, Fe, Ce, and $\mathrm{Sr}$ ) coatings on $\mathrm{LiCoO}_{2}$ cathode materials. J. Electrochem. Soc. 2005, 152, A1142-A1148. [CrossRef]

46. Tan, K.; Reddy, M.; Rao, G.S.; Chowdari, B. Effect of $\mathrm{AlPO}_{4}$-coating on cathodic behaviour of $\operatorname{Li}\left(\mathrm{Ni}_{0.8} \mathrm{Co}_{0.2}\right) \mathrm{O}_{2}$. J. Power Sources 2005, 141, 129-142. [CrossRef]

47. Sun, Y.K.; Han, J.M.; Myung, S.T.; Lee, S.W.; Amine, K. Significant improvement of high voltage cycling behavior $\mathrm{AlF}_{3}$-coated $\mathrm{LiCoO}_{2}$ cathode. Electrochem. Commun. 2006, 8, 821-826. [CrossRef]

48. Yang, Z.; Qiao, Q.; Yang, W. Improvement of structural and electrochemical properties of commercial $\mathrm{LiCoO}_{2}$ by coating with $\mathrm{LaF}_{3}$. Electrochim. Acta 2011, 56, 4791-4796. [CrossRef]

49. Park, J.S.; Mane, A.U.; Elam, J.W.; Croy, J.R. Amorphous metal fluoride passivation coatings prepared by atomic layer deposition on $\mathrm{LiCoO}_{2}$ for Li-ion batteries. Chem. Mater. 2015, 27, 1917-1920. [CrossRef]

50. Bai, Y.; Liu, N.; Liu, J.; Wang, Z.; Chen, L. Coating material-induced acidic electrolyte improves $\mathrm{LiCoO}_{2}$ performances. Electrochem. Solid State Lett. 2006, 9, A552-A556. [CrossRef]

51. Li, C.; Zhang, H.; Fu, L.; Liu, H.; Wu, Y.; Rahm, E.; Holze, R.; Wu, H. Cathode materials modified by surface coating for lithium ion batteries. Electrochim. Acta 2006, 51, 3872-3883. [CrossRef]

52. Cho, J.; Kim, Y.J.; Park, B. $\mathrm{LiCoO}_{2}$ cathode material that does not show a phase transition from hexagonal to monoclinic phase. J. Electrochem. Soc. 2001, 148, A1110-A1115. [CrossRef]

53. Kim, J.S.; Johnson, C.; Vaughey, J.; Hackney, S.; Walz, K.; Zeltner, W.; Anderson, M.; Thackeray, M. The electrochemical sability of spinel electrodes coated with $\mathrm{ZrO}_{2}, \mathrm{Al}_{2} \mathrm{O}_{3}$, and $\mathrm{SiO}_{2}$ from colloidal suspensions. J. Electrochem. Soc. 2004, 151, A1755-A1761. [CrossRef] 
54. Dahéron, L.; Dedryvere, R.; Martinez, H.; Flahaut, D.; Ménétrier, M.; Delmas, C.; Gonbeau, D. Possible explanation for the efficiency of Al-based coatings on $\mathrm{LiCoO}_{2}$ : Surface properties of $\mathrm{LiCo}_{1-\mathrm{x}} \mathrm{Al}_{\mathrm{x}} \mathrm{O}_{2}$ solid solution. Chem. Mater. 2009, 21,5607-5616. [CrossRef]

55. Kweon, H.J.; Park, J.; Seo, J.; Kim, G.; Jung, B.; Lim, H.S. Effects of metal oxide coatings on the thermal stability and electrical performance of $\mathrm{LiCoO}_{2}$ in a Li-ion cell. J. Power Sources 2004, 126, 156-162. [CrossRef]

56. Tan, K.; Reddy, M.; Rao, G.S.; Chowdari, B. High-performance $\mathrm{LiCoO}_{2}$ by molten salt $\left(\mathrm{LiNO}_{3}: \mathrm{LiCl}\right)$ synthesis for Li-ion batteries. J. Power Sources 2005, 147, 241-248. [CrossRef]

57. Xu, J.; Thomas, H.; Francis, R.W.; Lum, K.R.; Wang, J.; Liang, B. A review of processes and technologies for the recycling of lithium-ion secondary batteries. J. Power Sources 2008, 177, 512-527. [CrossRef]

58. Gaines, L. The future of automotive lithium-ion battery recycling: Charting a sustainable course. Sustain. Mater. Technol. 2014, 1, 2-7. [CrossRef]

59. Hirano, A.; Kanno, R.; Kawamoto, Y.; Takeda, Y.; Yamaura, K.; Takano, M.; Ohyama, K.; Ohashi, M.; Yamaguchi, Y. Relationship between non-stoichiometry and physical properties in $\mathrm{LiNiO}_{2}$. Solid State Ion. 1995, 78, 123-131. [CrossRef]

60. Cho, J.; Kim, T.-J.; Kim, Y.J.; Park, B. High-performance $\mathrm{ZrO}_{2}$-coated $\mathrm{LiNiO}_{2}$ cathode material. Electrochem. Solid State Lett. 2001, 4, A159-A161. [CrossRef]

61. Dahn, J.; Fuller, E.; Obrovac, M.; Von Sacken, U. Thermal stability of $\mathrm{Li}_{x} \mathrm{CoO}_{2}, \mathrm{LixNiO}_{2}$ and $\lambda-\mathrm{MnO}_{2}$ and consequences for the safety of Li-ion cells. Solid State Ion. 1994, 69, 265-270. [CrossRef]

62. Tey, S.L.; Reddy, M.; Subba Rao, G.; Chowdari, B.; Yi, J.; Ding, J.; Vittal, J.J. Synthesis, Structure, and Magnetic Properties of $\left[\mathrm{Li}\left(\mathrm{H}_{2} \mathrm{O}\right) \mathrm{M}\left(\mathrm{N}_{2} \mathrm{H}_{3} \mathrm{CO}_{2}\right)_{3}\right] \cdot 0.5 \mathrm{H}_{2} \mathrm{O}(\mathrm{M}=\mathrm{Co}, \mathrm{Ni})$ as Single Precursors to $\mathrm{LiMO}_{2}$ Battery Materials. Chem. Mater. 2006, 18, 1587-1594.

63. InvestmentMine. Commodity and Metal Prices. Available online: http://www.infomine.com/investment/ metal-prices/ (accessed on 10 May 2017).

64. Armstrong, A.R.; Bruce, P.G. Synthesis of layered $\mathrm{LiMnO}_{2}$ as an electrode for rechargeable lithium batteries. Nature 1996, 381, 499-500. [CrossRef]

65. Vitins, G.; West, K. Lithium intercalation into layered $\mathrm{LiMnO}_{2}$. J. Electrochem. Soc. 1997, 144, $2587-2592$. [CrossRef]

66. Cho, J.; Kim, T.J.; Park, B. The effect of a metal-oxide coating on the cycling behavior at $55{ }^{\circ} \mathrm{C}$ in orthorhombic $\mathrm{LiMnO}_{2}$ cathode materials. J. Electrochem. Soc. 2002, 149, A288-A292. [CrossRef]

67. Cho, J.; Kim, Y.J.; Kim, T.J.; Park, B. Enhanced structural stability of o-LiMnO 2 by sol-gel coating of $\mathrm{Al}_{2} \mathrm{O}_{3}$. Chem. Mater. 2001, 13, 18-20. [CrossRef]

68. Chikkannanavar, S.B.; Bernardi, D.M.; Liu, L. A review of blended cathode materials for use in Li-ion batteries. J. Power Sources 2014, 248, 91-100. [CrossRef]

69. Reddy, M.; Tung, B.D.; Yang, L.; Minh, N.D.Q.; Loh, K.; Chowdari, B. Molten salt method of preparation and cathodic studies on layered-cathode materials $\mathrm{Li}\left(\mathrm{Co}_{0.7} \mathrm{Ni}_{0.3}\right) \mathrm{O}_{2}$ and $\mathrm{Li}\left(\mathrm{Ni}_{0.7} \mathrm{Co}_{0.3}\right) \mathrm{O}_{2}$ for Li-ion batteries. J. Power Sources 2013, 225, 374-381.

70. Reddy, M.; Rao, G.S.; Chowdari, B. Synthesis by molten salt and cathodic properties of $\mathrm{Li}\left(\mathrm{Ni}_{1 / 3} \mathrm{Co}_{1 / 3} \mathrm{Mn}_{1 / 3}\right) \mathrm{O}_{2}$. J. Power Sources 2006, 159, 263-267. [CrossRef]

71. Reddy, M.; Rao, G.S.; Chowdari, B. Synthesis and electrochemical studies of the 4 V cathode, $\mathrm{Li}\left(\mathrm{Ni}_{2 / 3} \mathrm{Mn}_{1 / 3}\right) \mathrm{O}_{2}$. J. Power Sources 2006, 160, 1369-1374. [CrossRef]

72. Zhao, X.; Reddy, M.; Liu, H.; Rao, G.S.; Chowdari, B. Layered $\mathrm{Li}\left(\mathrm{Ni}_{0.2} \mathrm{Mn}_{0.2} \mathrm{Co}_{0.6}\right) \mathrm{O}_{2}$ synthesized by a molten salt method for lithium-ion batteries. RSC Adv. 2014, 4, 24538-24543.

73. Tan, T.Q.; Idris, M.S.; Osman, R.A.M.; Reddy, M.; Chowdari, B. Structure and electrochemical behaviour of $\mathrm{LiNi}_{0.4} \mathrm{Mn}_{0.4} \mathrm{Co}_{0.2} \mathrm{O}_{2}$ as cathode material for lithium ion batteries. Solid State Ion. 2015, 278, $43-48$.

74. Doughty, D.; Roth, E.P. A general discussion of Li ion battery safety. Electrochem. Soc. Interface 2012, $21,37-44$. [CrossRef]

75. Jang, D.H.; Shin, Y.J.; Oh, S.M. Dissolution of spinel oxides and capacity losses in $4 \mathrm{~V} \mathrm{Li} / \mathrm{Li}_{x} \mathrm{Mn}_{2} \mathrm{O}_{4}$ cells. J. Electrochem. Soc. 1996, 143, 2204-2211. [CrossRef]

76. Amatucci, G.; Blyr, A.; Sigala, C.; Alfonse, P.; Tarascon, J. Surface treatments of $\mathrm{Li}_{1+\mathrm{x}} \mathrm{Mn}_{2-\mathrm{x}} \mathrm{O}_{4}$ spinels for improved elevated temperature performance. Solid State Ion. 1997, 104, 13-25. [CrossRef]

77. Tsunekawa, H.; Tanimoto, S.; Marubayashi, R.; Fujita, M.; Kifune, K.; Sano, M. Capacity fading of graphite electrodes due to the deposition of manganese ions on them in Li-ion batteries. J. Electrochem. Soc. 2002, 149, A1326-A1331. [CrossRef] 
78. Arumugam, D.; Kalaignan, G.P. Synthesis and electrochemical characterizations of Nano-SiO ${ }_{2}$-coated $\mathrm{LiMn}_{2} \mathrm{O}_{4}$ cathode materials for rechargeable lithium batteries. J. Electroanal. Chem. 2008, 624, 197-204. [CrossRef]

79. Wang, L.; Zhao, J.; Guo, S.; He, X.; Jiang, C.; Wan, C. Investigation of $\mathrm{SnO}_{2}$-modified $\mathrm{LiMn}_{2} \mathrm{O}_{4}$ composite as cathode material for lithium-ion batteries. Int. J. Electrochem. Sci. 2010, 5, 1113-1126.

80. Gnanaraj, J.; Pol, V.; Gedanken, A.; Aurbach, D. Improving the high-temperature performance of $\mathrm{LiMn}_{2} \mathrm{O}_{4}$ spinel electrodes by coating the active mass with $\mathrm{MgO}$ via a sonochemical method. Electrochem. Commun. 2003, 5, 940-945. [CrossRef]

81. Zhou, W.J.; He, B.L.; Li, H.L. Synthesis, structure and electrochemistry of Ag-modified $\mathrm{LiMn}_{2} \mathrm{O}_{4}$ cathode materials for lithium-ion batteries. Mater. Res. Bull. 2008, 43, 2285-2294. [CrossRef]

82. Huang, S.; Wen, Z.; Yang, X.; Zhu, X.; Lin, B. Synthesis and the Improved High-Rate Performance of $\mathrm{LiMn}_{2} \mathrm{O}_{4} / \mathrm{Ag}$ Composite Cathode for Lithium-Ion Batteries. Electrochem. Solid State Lett. 2006, 9, A443-A447. [CrossRef]

83. Ding, Y.; Xie, J.; Cao, G.; Zhu, T.; Yu, H.; Zhao, X. Enhanced elevated-temperature performance of Al-doped single-crystalline $\mathrm{LiMn}_{2} \mathrm{O}_{4}$ nanotubes as cathodes for lithium ion batteries. J. Phys. Chem. C 2011, 115, 9821-9825. [CrossRef]

84. Jia, X.; Yan, C.; Chen, Z.; Wang, R.; Zhang, Q.; Guo, L.; Wei, F.; Lu, Y. Direct growth of flexible $\mathrm{LiMn}_{2} \mathrm{O}_{4} / \mathrm{CNT}$ lithium-ion cathodes. Chem. Commun. 2011, 47, 9669-9671. [CrossRef] [PubMed]

85. Cho, J.; Kim, G.B.; Lim, H.S.; Kim, C.S.; Yoo, S.I. Improvement of structural stability of $\mathrm{LiMn}_{2} \mathrm{O}_{4}$ cathode material on $55{ }^{\circ} \mathrm{C}$ cycling by sol-gel coating of $\mathrm{LiCoO}_{2}$. Electrochem. Solid State Lett. 1999, 2, 607-609. [CrossRef]

86. Kitao, H.; Fujihara, T.; Takeda, K.; Nakanishi, N.; Nohma, T. High-temperature storage performance of $\mathrm{Li}$-ion batteries using a mixture of Li-Mn spinel and $\mathrm{Li}-\mathrm{Ni}-\mathrm{Co}-\mathrm{Mn}$ oxide as a positive electrode material. Electrochem. Solid State Lett. 2005, 8, A87-A90. [CrossRef]

87. Yi, T.F.; Zhu, Y.R.; Zhu, X.D.; Shu, J.; Yue, C.B.; Zhou, A.N. A review of recent developments in the surface modification of $\mathrm{LiMn}_{2} \mathrm{O}_{4}$ as cathode material of power lithium-ion battery. Ionics 2009, 15, 779-784. [CrossRef]

88. Prabu, M.; Reddy, M.; Selvasekarapandian, S.; Rao, G.S.; Chowdari, B. (Li, Al)-co-doped spinel, $\mathrm{Li}\left(\mathrm{Li}_{0.1} \mathrm{Al}_{0.1} \mathrm{Mn}_{1.8}\right) \mathrm{O}_{4}$ as high performance cathode for lithium ion batteries. Electrochim. Acta 2013, 88, 745-755.

89. Zhao, X.; Reddy, M.; Liu, H.; Ramakrishna, S.; Rao, G.S.; Chowdari, B.V. Nano $\mathrm{LiMn}_{2} \mathrm{O}_{4}$ with spherical morphology synthesized by a molten salt method as cathodes for lithium ion batteries. RSC Adv. 2012, 2, 7462-7469. [CrossRef]

90. Sakunthala, A.; Reddy, M.; Selvasekarapandian, S.; Chowdari, B.; Selvin, P.C. Synthesis of compounds, $\mathrm{Li}\left(\mathrm{MMn}_{11 / 6}\right) \mathrm{O}_{4}\left(\mathrm{M}=\mathrm{Mn}_{1 / 6}, \mathrm{Co}_{1 / 6},\left(\mathrm{Co}_{1 / 12} \mathrm{Cr}_{1 / 12}\right),\left(\mathrm{Co}_{1 / 12} \mathrm{Al}_{1 / 12}\right),\left(\mathrm{Cr}_{1 / 12} \mathrm{Al}_{1 / 12}\right)\right)$ by polymer precursor method and its electrochemical performance for lithium-ion batteries. Electrochim. Acta 2010, 55, 4441-4450. [CrossRef]

91. Reddy, M.; Sakunthala, A.; SelvashekaraPandian, S.; Chowdari, B. Preparation, Comparative Energy Storage Properties, and Impedance Spectroscopy Studies of Environmentally Friendly Cathode, Li $\left(\mathrm{MMn}_{11 / 6}\right) \mathrm{O} 4(\mathrm{M}$ $\left.=\mathrm{Mn}_{1 / 6}, \mathrm{Co}_{1 / 6},\left(\mathrm{Co}_{1 / 12} \mathrm{Cr}_{1 / 12}\right)\right)$. J. Phys. Chem. C 2013, 117, 9056-9064. [CrossRef]

92. Reddy, M.; Manoharan, S.S.; John, J.; Singh, B.; Rao, G.S.; Chowdari, B. Synthesis, Characterization, and Electrochemical Cycling Behavior of the Ru-Doped Spinel, $\mathrm{Li}\left[\mathrm{Mn}_{2-\mathrm{x}} \mathrm{Ru}_{\mathrm{x}}\right] \mathrm{O}_{4}(\mathrm{x}=0,0.1$, and 0.25). J. Electrochem. Soc. 2009, 156, A652-A660. [CrossRef]

93. Reddy, M.; Cheng, H.; Tham, J.; Yuan, C.; Goh, H.; Chowdari, B. Preparation of $\mathrm{Li}\left(\mathrm{Ni}_{0.5} \mathrm{Mn}_{1.5}\right) \mathrm{O}_{4}$ by polymer precursor method and its electrochemical properties. Electrochim. Acta 2012, 62, 269-275.

94. Reddy, M.; Raju, M.S.; Sharma, N.; Quan, P.; Nowshad, S.H.; Emmanuel, H.C.; Peterson, V.; Chowdari, B. Preparation of $\mathrm{Li}_{1.03} \mathrm{Mn}_{1.97} \mathrm{O}_{4}$ and $\mathrm{Li}_{1.06} \mathrm{Mn}_{1.94} \mathrm{O}_{4}$ by the polymer precursor method and $\mathrm{X}$-ray, neutron diffraction and electrochemical studies. J. Electrochem. Soc. 2011, 158, A1231-A1236.

95. Wei, Y.; Yan, L.; Wang, C.; Xu, X.; Wu, F.; Chen, G. Effects of Ni doping on $\left[\mathrm{MnO}_{6}\right]$ octahedron in $\mathrm{LiMn}_{2} \mathrm{O}_{4}$. J. Phys. Chem. B 2004, 108, 18547-18551. [CrossRef]

96. Liu, Q.; Wang, S.; Tan, H.; Yang, Z.; Zeng, J. Preparation and doping mode of doped $\mathrm{LiMn}_{2} \mathrm{O}_{4}$ for $\mathrm{Li}$-ion batteries. Energies 2013, 6, 1718-1730. [CrossRef] 
97. Masquelier, C.; Croguennec, L. Polyanionic (phosphates, silicates, sulfates) frameworks as electrode materials for rechargeable Li (or Na) batteries. Chem. Rev. 2013, 113, 6552-6591. [CrossRef] [PubMed]

98. Ravet, N.; Goodenough, J.; Besner, S.; Simoneau, M.; Hovington, P.; Armand, M. Improved iron based cathode material. In Proceedings of the 196th ECS meeting, Honolulu, HI, USA, 17-22 October 1999.

99. Yamada, A.; Chung, S.C.; Hinokuma, K. Optimized $\mathrm{LiFePO}_{4}$ for lithium battery cathodes. J. Electrochem. Soc. 2001, 148, A224-A229. [CrossRef]

100. Saravanan, K.; Reddy, M.; Balaya, P.; Gong, H.; Chowdari, B.; Vittal, J.J. Storage performance of LiFePO 4 nanoplates. J. Mater. Chem. 2009, 19, 605-610. [CrossRef]

101. Doeff, M.M.; Hu, Y.; McLarnon, F.; Kostecki, R. Effect of surface carbon structure on the electrochemical performance of $\mathrm{LiFePO}_{4}$. Electrochem. Solid State Lett. 2003, 6, A207-A209. [CrossRef]

102. Wilcox, J.D.; Doeff, M.M.; Marcinek, M.; Kostecki, R. Factors influencing the quality of carbon coatings on $\mathrm{LiFePO}_{4}$. J. Electrochem. Soc. 2007, 154, A389-A395. [CrossRef]

103. Zaghib, K.; Shim, J.; Guerfi, A.; Charest, P.; Striebel, K. Effect of carbon source as additives in $\mathrm{LiFePO}_{4}$ as positive electrode for lithium-ion batteries. Electrochem. Solid State Lett. 2005, 8, A207-A210. [CrossRef]

104. Dominko, R.; Bele, M.; Gaberscek, M.; Remskar, M.; Hanzel, D.; Pejovnik, S.; Jamnik, J. Impact of the carbon coating thickness on the electrochemical performance of $\mathrm{LiFePO}_{4} / \mathrm{C}$ composites. J. Electrochem. Soc. 2005, 152, A607-A610. [CrossRef]

105. Hu, Y.; Doeff, M.M.; Kostecki, R.; Finones, R. Electrochemical performance of sol-gel synthesized $\mathrm{LiFePO}_{4}$ in lithium batteries. J. Electrochem. Soc. 2004, 151, A1279-A1285. [CrossRef]

106. Jinli, Z.; Jiao, W.; Yuanyuan, L.; Ning, N.; Junjie, G.; Feng, Y.; Wei, L. High-performance lithium iron phosphate with phosphorus-doped carbon layers for lithium ion batteries. J. Mater. Chem. A 2015, 3, 2043-2049. [CrossRef]

107. Zhang, J.; Nie, N.; Liu, Y.; Wang, J.; Yu, F.; Gu, J.; Li, W. Boron and nitrogen codoped carbon layers of $\mathrm{LiFePO}_{4}$ improve the high-rate electrochemical performance for lithium ion batteries. ACS Appl. Mater. Interfaces 2015, 7, 20134-20143. [CrossRef] [PubMed]

108. Rao, R.P.; Reddy, M.; Adams, S.; Chowdari, B. Preparation, temperature dependent structural, molecular dynamics simulations studies and electrochemical properties of $\mathrm{LiFePO}_{4}$. Mater. Res. Bull. 2015, 66, 71-75. [CrossRef]

109. Zhou, Y.; Wang, J.; Hu, Y.; O'Hayre, R.; Shao, Z. A porous $\mathrm{LiFePO}_{4}$ and carbon nanotube composite. Chem. Commun. 2010, 46, 7151-7153. [CrossRef] [PubMed]

110. Yang, J.; Wang, J.; Wang, D.; Li, X.; Geng, D.; Liang, G.; Gauthier, M.; Li, R.; Sun, X. 3D porous $\mathrm{LiFePO}_{4}$ /graphene hybrid cathodes with enhanced performance for Li-ion batteries. J. Power Sources 2012, 208, 340-344. [CrossRef]

111. Shi, Y.; Chou, S.L.; Wang, J.Z.; Wexler, D.; Li, H.J.; Liu, H.K.; Wu, Y. Graphene wrapped $\mathrm{LiFePO}_{4} / \mathrm{C}$ composites as cathode materials for Li-ion batteries with enhanced rate capability. J. Mater. Chem. 2012, 22, 16465-16470. [CrossRef]

112. Hu, L.H.; Wu, F.Y.; Lin, C.T.; Khlobystov, A.N.; Li, L.J. Graphene-modified $\mathrm{LiFePO}_{4}$ cathode for lithium ion battery beyond theoretical capacity. Nat. Commun. 2013, 4, 1687. [CrossRef] [PubMed]

113. Yang, J.; Wang, J.; Tang, Y.; Wang, D.; Xiao, B.; Li, X.; Li, R.; Liang, G.; Sham, T.K.; Sun, X. In situ self-catalyzed formation of core-shell $\mathrm{LiFePO}_{4} @ \mathrm{CNT}$ nanowires for high rate performance lithium-ion batteries. J. Mater. Chem. A 2013, 1, 7306-7311. [CrossRef]

114. Yang, J.; Wang, J.; Li, X.; Wang, D.; Liu, J.; Liang, G.; Gauthier, M.; Li, Y.; Geng, D.; Li, R. Hierarchically porous $\mathrm{LiFePO}_{4} /$ nitrogen-doped carbon nanotubes composite as a cathode for lithium ion batteries. J. Mater. Chem. 2012, 22, 7537-7543. [CrossRef]

115. Reddy, M.; Rao, G.S.; Chowdari, B. Long-term cycling studies on 4 V-cathode, lithium vanadium fluorophosphate. J. Power Sources 2010, 195, 5768-5774. [CrossRef]

116. Hameed, A.S.; Nagarathinam, M.; Reddy, M.; Chowdari, B.; Vittal, J.J. Synthesis and electrochemical studies of layer-structured metastable $\alpha$ i-LiVOPO 4 . J. Mater. Chem. 2012, 22, 7206-7213. [CrossRef]

117. Hameed, A.S.; Reddy, M.; Chowdari, B.; Vittal, J.J. Carbon coated $\mathrm{Li}_{3} \mathrm{~V}_{2}\left(\mathrm{PO}_{4}\right)_{3}$ from the single-source precursor, $\mathrm{Li}_{2}(\mathrm{VO})_{2}\left(\mathrm{HPO}_{4}\right)_{2}\left(\mathrm{C}_{2} \mathrm{O}_{4}\right) \cdot 6 \mathrm{H}_{2} \mathrm{O}$ as cathode and anode materials for Lithium ion batteries. Electrochim. Acta 2014, 128, 184-191. [CrossRef] 
118. Nagarathinam, M.; Saravanan, K.; Phua, E.J.H.; Reddy, M.; Chowdari, B.; Vittal, J.J. Redox-Active Metal-Centered Oxalato Phosphate Open Framework Cathode Materials for Lithium Ion Batteries. Angew. Chem. Int. Ed. 2012, 51, 5866-5870. [CrossRef] [PubMed]

119. Hameed, A.S.; Reddy, M.; Nagarathinam, M.; Runčevski, T.; Dinnebier, R.E.; Adams, S.; Chowdari, B.; Vittal, J.J. Room temperature large-scale synthesis of layered frameworks as low-cost $4 \mathrm{~V}$ cathode materials for lithium ion batteries. Sci. Rep. 2015, 5, 16270. [CrossRef] [PubMed]

120. Hameed, A.S.; Reddy, M.; Sarkar, N.; Chowdari, B.; Vittal, J.J. Synthesis and electrochemical investigation of novel phosphite based layered cathodes for Li-ion batteries. RSC Adv. 2015, 5, 60630-60637. [CrossRef]

121. Hameed, A.S.; Nagarathinam, M.; Schreyer, M.; Reddy, M.; Chowdari, B.; Vittal, J.J. A layered oxalatophosphate framework as a cathode material for Li-ion batteries. J. Mater. Chem. A 2013, 1, 5721-5726. [CrossRef]

122. Ke, F.S.; Wu, Y.S.; Deng, H. Metal-organic frameworks for lithium ion batteries and supercapacitors. J. Solid State Chem. 2015, 223, 109-121. [CrossRef]

123. Bai, L.; Tu, B.; Qi, Y.; Gao, Q.; Liu, D.; Liu, Z.; Zhao, L.; Li, Q.; Zhao, Y. Enhanced performance in gas adsorption and $\mathrm{Li}$ ion batteries by docking $\mathrm{Li}^{+}$in a crown ether-based metal-organic framework. Chem. Commun. 2016, 52, 3003-3006. [CrossRef] [PubMed]

124. Banerjee, A.; Singh, U.; Aravindan, V.; Srinivasan, M.; Ogale, S. Synthesis of CuO nanostructures from Cu-based metal organic framework (MOF-199) for application as anode for Li-ion batteries. Nano Energy 2013, 2, 1158-1163. [CrossRef]

125. Wu, Y.P.; Rahm, E.; Holze, R. Carbon anode materials for lithium ion batteries. J. Power Sources 2003, 114, 228-236. [CrossRef]

126. Roberts, A.D.; Li, X.; Zhang, H. Porous carbon spheres and monoliths: Morphology control, pore size tuning and their applications as Li-ion battery anode materials. Chem. Soc. Rev. 2014, 43, 4341-4356. [CrossRef] [PubMed]

127. Buiel, E.; Dahn, J. Li-insertion in hard carbon anode materials for Li-ion batteries. Electrochim. Acta 1999, 45, 121-130. [CrossRef]

128. Nishimura, K.; Honbo, H.; Takeuchi, S.; Horiba, T.; Oda, M.; Koseki, M.; Muranaka, Y.; Kozono, Y.; Miyadera, H. Design and performance of $10 \mathrm{Wh}$ rechargeable lithium batteries. J. Power Sources 1997, 68, 436-439. [CrossRef]

129. Wu, Y.; Jiang, C.; Wan, C.; Holze, R. Composite materials of silver and natural graphite as anode with low sensibility to humidity. J. Power Sources 2002, 112, 255-260. [CrossRef]

130. Wu, Y.; Jiang, C.; Wan, C.; Tsuchida, E. Composite anode material for lithium ion battery with low sensitivity to water. Electrochem. Commun. 2000, 2, 626-629. [CrossRef]

131. Yu, P.; Ritter, J.A.; White, R.E.; Popov, B.N. Ni-composite microencapsulated graphite as the negative electrode in lithium-ion batteries I. Initial irreversible capacity study. J. Electrochem. Soc. 2000, 147, 1280-1285. [CrossRef]

132. Yu, P.; Ritter, J.A.; White, R.E.; Popov, B.N. Ni-composite microencapsulated graphite as the negative electrode in lithium-ion batteries II: Electrochemical impedance and self-discharge studies. J. Electrochem. Soc. 2000, 147, 2081-2085. [CrossRef]

133. Guo, K.; Pan, Q.; Wang, L.; Fang, S. Nano-scale copper-coated graphite as anode material for lithium-ion batteries. J. Appl. Electrochem. 2002, 32, 679-685. [CrossRef]

134. Kim, S.-S.; Kadoma, Y.; Ikuta, H.; Uchimoto, Y.; Wakihara, M. Electrochemical performance of natural graphite by surface modification using aluminum. Electrochem. Solid State Lett. 2001, 4, A109-A112. [CrossRef]

135. Takamura, T.; Sumiya, K.; Suzuki, J.; Yamada, C.; Sekine, K. Enhancement of Li doping/undoping reaction rate of carbonaceous materials by coating with an evaporated metal film. J. Power Sources 1999, 81, 368-372. [CrossRef]

136. Yoshio, M.; Wang, H.; Fukuda, K.; Umeno, T.; Abe, T.; Ogumi, Z. Improvement of natural graphite as a lithium-ion battery anode material, from raw flake to carbon-coated sphere. J. Mater. Chem. 2004, 14, 1754-1758. [CrossRef]

137. Wang, H.; Yoshio, M. Carbon-coated natural graphite prepared by thermal vapor decomposition process, a candidate anode material for lithium-ion battery. J. Power Sources 2001, 93, 123-129. [CrossRef]

138. Natarajan, C.; Fujimoto, H.; Tokumitsu, K.; Mabuchi, A.; Kasuh, T. Reduction of the irreversible capacity of a graphite anode by the CVD process. Carbon 2001, 39, 1409-1413. [CrossRef] 
139. Yoshio, M.; Wang, H.; Fukuda, K.; Hara, Y.; Adachi, Y. Effect of carbon coating on electrochemical performance of treated natural graphite as lithium-ion battery anode material. J. Electrochem. Soc. 2000, 147, 1245-1250. [CrossRef]

140. Dey, A.; Sullivan, B. The electrochemical decomposition of propylene carbonate on graphite. J. Electrochem. Soc. 1970, 117, 222-224. [CrossRef]

141. Jeong, G.; Kim, Y.U.; Kim, H.; Kim, Y.J.; Sohn, H.J. Prospective materials and applications for Li secondary batteries. Energy Environ. Sci. 2011, 4, 1986-2002. [CrossRef]

142. Aurbach, D.; Zinigrad, E.; Cohen, Y.; Teller, H. A short review of failure mechanisms of lithium metal and lithiated graphite anodes in liquid electrolyte solutions. Solid State Ion. 2002, 148, 405-416. [CrossRef]

143. Beattie, S.D.; Larcher, D.; Morcrette, M.; Simon, B.; Tarascon, J.M. Si electrodes for Li-ion batteries-a new way to look at an old problem. J. Electrochem. Soc. 2008, 155, A158-A163. [CrossRef]

144. Lee, H.Y.; Lee, S.M. Carbon-coated nano-Si dispersed oxides/graphite composites as anode material for lithium ion batteries. Electrochem. Commun. 2004, 6, 465-469. [CrossRef]

145. Wen, Z.; Yang, J.; Wang, B.; Wang, K.; Liu, Y. High capacity silicon/carbon composite anode materials for lithium ion batteries. Electrochem. Commun. 2003, 5, 165-168. [CrossRef]

146. Yoshio, M.; Wang, H.; Fukuda, K.; Umeno, T.; Dimov, N.; Ogumi, Z. Carbon-coated Si as a lithium-ion battery anode material. J. Electrochem. Soc. 2002, 149, A1598-A1603. [CrossRef]

147. Wang, G.; Ahn, J.; Yao, J.; Bewlay, S.; Liu, H. Nanostructured Si-C composite anodes for lithium-ion batteries. Electrochem. Commun. 2004, 6, 689-692. [CrossRef]

148. Liu, N.; Wu, H.; McDowell, M.T.; Yao, Y.; Wang, C.; Cui, Y. A yolk-shell design for stabilized and scalable Li-ion battery alloy anodes. Nano Lett. 2012, 12, 3315-3321. [CrossRef] [PubMed]

149. Liu, N.; Lu, Z.; Zhao, J.; McDowell, M.T.; Lee, H.W.; Zhao, W.; Cui, Y. A pomegranate-inspired nanoscale design for large-volume-change lithium battery anodes. Nat. Nanotechnol. 2014, 9, 187-192. [CrossRef] [PubMed]

150. Mazouzi, D.; Karkar, Z.; Hernandez, C.R.; Manero, P.J.; Guyomard, D.; Roué, L.; Lestriez, B. Critical roles of binders and formulation at multiscales of silicon-based composite electrodes. J. Power Sources 2015, 280, 533-549. [CrossRef]

151. Huang, Y.H.; Goodenough, J.B. High-rate $\mathrm{LiFePO}_{4}$ lithium rechargeable battery promoted by electrochemically active polymers. Chem. Mater. 2008, 20, 7237-7241. [CrossRef]

152. Chen, W.M.; Qie, L.; Yuan, L.X.; Xia, S.A.; Hu, X.L.; Zhang, W.X.; Huang, Y.H. Insight into the improvement of rate capability and cyclability in $\mathrm{LiFePO}_{4}$ /polyaniline composite cathode. Electrochim. Acta 2011, 56, 2689-2695. [CrossRef]

153. Tamura, T.; Aoki, Y.; Ohsawa, T.; Dokko, K. Polyaniline as a functional binder for $\mathrm{LiFePO}_{4}$ cathodes in lithium batteries. Chem. Lett. 2011, 40, 828-830. [CrossRef]

154. Huang, Y.H.; Park, K.S.; Goodenough, J.B. Improving lithium batteries by tethering carbon-coated $\mathrm{LiFePO}_{4}$ to polypyrrole. J. Electrochem. Soc. 2006, 153, A2282-A2286. [CrossRef]

155. Dominko, R.; Gaberšček, M.; Drofenik, J.; Bele, M.; Pejovnik, S. A novel coating technology for preparation of cathodes in Li-ion batteries. Electrochem. Solid State Lett. 2001, 4, A187-A190. [CrossRef]

156. Chen, Z.; Christensen, L.; Dahn, J. Comparison of PVDF and PVDF-TFE-P as binders for electrode materials showing large volume changes in lithium-ion batteries. J. Electrochem. Soc. 2003, 150, A1073-A1078. [CrossRef]

157. Chen, Z.; Christensen, L.; Dahn, J. Large-volume-change electrodes for Li-ion batteries of amorphous alloy particles held by elastomeric tethers. Electrochem. Commun. 2003, 5, 919-923. [CrossRef]

158. Liu, W.R.; Yang, M.H.; Wu, H.C.; Chiao, S.; Wu, N.L. Enhanced cycle life of Si anode for Li-ion batteries by using modified elastomeric binder. Electrochem. Solid State Lett. 2005, 8, A100-A103. [CrossRef]

159. Koo, B.; Kim, H.; Cho, Y.; Lee, K.T.; Choi, N.S.; Cho, J. A Highly cross-linked polymeric binder for high-performance silicon negative electrodes in lithium ion batteries. Angew. Chem. Int. Ed. 2012, 51, 8762-8767. [CrossRef] [PubMed]

160. Kwon, T.W.; Jeong, Y.K.; Deniz, E.; AlQaradawi, S.Y.; Choi, J.W.; Coskun, A. Dynamic cross-linking of polymeric binders based on host-guest interactions for silicon anodes in lithium ion batteries. ACS Nano 2015, 9, 11317-11324. [CrossRef] [PubMed]

161. Arora, P.; Zhang, Z. Battery separators. Chem. Rev. 2004, 104, 4419-4462. [CrossRef] [PubMed] 
162. Song, J.; Ryou, M.H.; Son, B.; Lee, J.N.; Lee, D.J.; Lee, Y.M.; Choi, J.W.; Park, J.K. Co-polyimide-coated polyethylene separators for enhanced thermal stability of lithium ion batteries. Electrochim. Acta 2012, 85, 524-530. [CrossRef]

163. Liu, H.; Xu, J.; Guo, B.; He, X. Effect of $\mathrm{Al}_{2} \mathrm{O}_{3} / \mathrm{SiO}_{2}$ composite ceramic layers on performance of polypropylene separator for lithium-ion batteries. Ceram. Int. 2014, 40, 14105-14110. [CrossRef]

164. Choi, J.A.; Kim, S.H.; Kim, D.W. Enhancement of thermal stability and cycling performance in lithium-ion cells through the use of ceramic-coated separators. J. Power Sources 2010, 195, 6192-6196. [CrossRef]

165. Ryou, M.H.; Lee, Y.M.; Park, J.K.; Choi, J.W. Mussel-inspired polydopamine-treated polyethylene separators for high-power Li-ion batteries. Adv. Mater. 2011, 23, 3066-3070. [CrossRef] [PubMed]

166. Lee, J.Y.; Lee, Y.M.; Bhattacharya, B.; Nho, Y.C.; Park, J.K. Separator grafted with siloxane by electron beam irradiation for lithium secondary batteries. Electrochim. Acta 2009, 54, 4312-4315. [CrossRef]

167. Ko, J.; Min, B.; Kim, D.W.; Ryu, K.; Kim, K.; Lee, Y.; Chang, S. Thin-film type Li-ion battery, using a polyethylene separator grafted with glycidyl methacrylate. Electrochim. Acta 2004, 50, 367-370. [CrossRef]

168. Zhang, S.S. A review on the separators of liquid electrolyte Li-ion batteries. J. Power Sources 2007, 164, 351-364. [CrossRef]

(C) 2017 by the authors. Licensee MDPI, Basel, Switzerland. This article is an open access article distributed under the terms and conditions of the Creative Commons Attribution (CC BY) license (http://creativecommons.org/licenses/by/4.0/). 